\title{
A Comparative Review of the Extrinsic and Intrinsic Factors Regulating Lactose Synthesis
}

\author{
Anna Sadovnikova ${ }^{1,3}\left[\right.$ [D $\cdot$ Sergio C. Garcia ${ }^{2}\left[\right.$ [ $\cdot$ Russell C. Hovey ${ }^{3}$
}

Received: 31 August 2020 / Accepted: 20 May 2021 / Published online: 14 June 2021

(c) The Author(s) 2021

\begin{abstract}
Milk is critical for the survival of all mammalian offspring, where its production by a mammary gland is also positively associated with its lactose concentration. A clearer understanding of the factors that regulate lactose synthesis stands to direct strategies for improving neonatal health while also highlighting opportunities to manipulate and improve milk production and composition. In this review we draw a cross-species comparison of the extra- and intramammary factors that regulate lactose synthesis, with a special focus on humans, dairy animals, and rodents. We outline the various factors known to influence lactose synthesis including diet, hormones, and substrate supply, as well as the intracellular molecular and genetic mechanisms. We also discuss the strengths and limitations of various in vivo and in vitro systems for the study of lactose synthesis, which remains an important research gap.
\end{abstract}

Keywords Glucocorticoid $\cdot$ Prolactin $\cdot$ Insulin $\cdot$ Mammary culture $\cdot$ Alpha-lactalbumin

\section{Introduction}

The synthesis of lactose by the mammary epithelium occurs through a unique and conserved pathway that also varies across species. In a previous companion review [1], we outlined the extramammary, intramammary, and intracellular processes that direct lactose synthesis and secretion. The principal mechanisms involved in these processes include factors, such as diet and hormones and those specific to the transcription and post-translational modification of $\alpha$-lactalbumin (LALBA). Not surprisingly, various species have evolved different approaches to regulate lactose production, which underscores the importance of selecting the appropriate model(s) for translational studies. In this manuscript we use a comparative, cross-species approach to review the key regulators and control points that modulate

Anna Sadovnikova

asadovnikova@ucdavis.edu

1 Graduate Group in Nutritional Biology, Physician Scientist Training Program, University of California, Davis, CA, United States

2 School of Life and Environmental Sciences, University of Sydney, Sydney, Australia

3 Department of Animal Science, University of California, Davis, CA, United States lactose synthesis and, in the process, outline the strengths and limitations of different in vivo and ex vivo/in vitro methods that have been used to generate these data.

\section{Biphasic Regulation of Lactose Synthesis by Plasma Glucose Levels}

Given our goal is to review the many different control points that regulate lactose synthesis, we start here by outlining the effect that glucose supply and availability can impart on the mammary epithelium. As described earlier [1], plasma glucose is the main precursor for lactose synthesis and plays a key role in determining milk volume. However, the effect of its availability on milk lactose yield or content is biphasic, as demonstrated through a range of studies in dairy cows using post-ruminal infusion of starch, glucose, or gluconeogenic precursors (i.e., casein) [2-5]. Of these, the most direct approach for studying the effect of plasma glucose on milk composition is close-arterial provision of different doses of glucose directly to the mammary gland [6].

At suboptimal plasma glucose levels, mammary blood flow becomes the primary driver of lactose production [5, 7-10]. For example, when undernourished lactating goats were infused with glucose, the yield and content of lactose in milk were highest when 50 or $60 \mathrm{~g}$ of glucose was infused 
per day. Specifically, when $60 \mathrm{~g}$ of glucose was infused, lactose content and yield increased to $48.1 \mathrm{mg} / \mathrm{ml}$ and $41 \mathrm{~g}$ from $46.4 \mathrm{mg} / \mathrm{ml}$ and $33.3 \mathrm{~g}$, respectively, at baseline [6]. Mammary blood flow also increased in response to up to $60 \mathrm{~g} / \mathrm{d}$ of exogenous glucose, then remained stable at levels of 80 or $100 \mathrm{~g} / \mathrm{d}$, while milk lactose content and yield decreased to baseline values ( $46.5 \mathrm{mg} / \mathrm{ml}$ and $35.1 \mathrm{~g}$, respectively) at the $100 \mathrm{~g} / \mathrm{d}$ dose [6]. Importantly, the level of glucose extracted by the mammary epithelium was constant across all doses. Likewise, the milk fat and protein content was not affected by the glucose dose [6]. During these states of adequate glucose availability there was also a parallel decrease in the level of glucose-6-phosphate in the mammary tissue and/or milk, as occurs in both rats [11, 12] and goats [6].

On the other hand, during states of excess glucose supply there is a shift toward the intracellular accumulation of glucose metabolites that can suppress lactose synthesis. When $80 \mathrm{~g} / \mathrm{d}$ glucose was infused to the udder, goats transitioned from negative to positive energy balance, and a larger amount of glucose left the gland unused [6]. A parallel indication of this shuttling of glucose away from lactose synthesis is the accumulation of glucose-6-phosphate in the mammary epithelium or milk. In dairy cows receiving excess glucose via post-ruminal infusion, the concentration of glucose-6-phosphate in milk increased while that of glucose-1-phosphate decreased [5]. These changes may reflect the actions of insulin (INS) responding to increased plasma glucose levels, where INS is a strong negative regulator of phosphofructokinase, which would lead to an increase in glucose-6-phosphate levels $[6,13]$.

The role of plasma glucose concentration and supply in the regulation of lactose synthesis in lactating humans remains less clear. Certainly the negative effect of hypoglycemia on breast milk lactose and yield in the setting of a prolonged fast is well-established [14-16]. However, the question of how excess plasma glucose modulates lactose synthesis still requires investigation. Whereas Neville et al. concluded that the elevation of plasma glucose to $8 \mathrm{mmol} / \mathrm{l}$ for 4-6 h did not impact milk lactose content or the rate of lactose synthesis [17], this level of plasma glucose is within normal limits for postprandial glucose levels. In a subsequent smaller experiment with three breastfeeding humans producing less than $500 \mathrm{ml}$ daily, elevation of plasma glucose levels to $8 \mathrm{mmol} / \mathrm{l}$ resulted in a numerical increase in the lactose concentration in milk, from 189 to $203 \mathrm{mmol} / \mathrm{l}$ [17]. In our view, these findings warrant further validation in a well-powered study to clarify how varying plasma glucose levels impact milk lactose yield or content in humans.

In summary, it appears there is a biphasic effect of plasma glucose levels on lactose synthesis across ruminant and nonruminant species. It must be noted that the physiology, lactose precursor requirements, evolutionary adaptations, and milk composition of ruminants and non-ruminants differ, and specific conclusions regarding the mechanism in one species cannot be attributed to that of another. It is tempting to speculate that at suboptimal plasma glucose levels, mammary blood flow is the predominant player in the regulation of lactose synthesis, while at excess plasma glucose levels, the accumulation of intracellular intermediates in the MEC contributes to a downregulation of lactose synthesis. It remains to be determined how, at the genetic, biochemical, and cellular level, this occurs and whether insights into this mechanism can be harnessed for tailored interventions to improve outcomes for those with metabolic dysregulation (i.e., diabetes mellitus or ketosis).

\section{The Hormonal Regulation of LALBA and B4GALT1 Synthesis}

As we discussed previously [1], the abundance of LALBA and $\beta-1,4-$ Galactosyltransferase-1 (B4GALT1) is a key determinants for lactose synthesis, where their expression in the mammary epithelium is tightly regulated by critical hormones, including prolactin (PRL), glucocorticoid (GC), INS, triiodothyroinine (T3) and epidermal growth factor (EGF). Here we outline how these factors individually, or combined, can alter LALBA and B4GALT1 synthesis, with a prefaced overview of different in vitro systems that have been used to draw these conclusions.

\section{In Vitro Models for Studying LALBA and B4GALT1}

Despite their widespread adoption and utility, as well as their essential role in defining biological mechanisms, various culture models face the significant limitation that they do not faithfully recapitulate the extent of lactose synthesis and secretion that occurs in vivo. In many ways, this longstanding conclusion is unsurprising given that MEC within the gland must coordinately associate with other epithelial cells, stroma, and the vasculature to achieve complete functional differentiation. While some aspects of differentiation such as the formation of dome-like structures do occur in primary cultures of MEC, the primary milk proteins they synthesize are caseins such as B-casein (CSN2), but not LALBA, which emphasizes that these cultures are more representative of an early- to midpregnant state [18]. As pointed out by others, gene expression for CSN2 and the appearance of cytoplasmic lipid droplets do not reflect secretory activation (also known as lactogenesis II) [19-21]. One exception to these limitations is a system that used a $>2$-week lag in culture, which conferred hormonal sensitivity to primary MEC that went on to synthesize and secrete LALBA into the medium ( 1-10 ng/ml/day) [22].

Among the different ex vivo/in vitro systems available, different lines of evidence support that explanted 
mammary tissue best-approximates the in vivo state. When mammary glands from midpregnant or pseudopregnant mice were dissociated to acinar fragments or diced into explants, MEC maintained cell-cell associations, their cuboidal shape, and synthesized LALBA and lactose [23-25]. However, the use of mammary explants as a model faces certain limitations. Within hours of exposure to PRL, INS, and GC, explants from midpregnant mice had a transcriptomic signature similar to that recorded during secretory differentiation in vivo. By contrast, prolonged stimulation by a hormonal combination that would normally accompany secretory activation in vivo resulted in a transcriptomic signature that was vastly different from that described in fresh mammary tissue isolated from mice during early lactation [26]. A parallel challenge is sustaining the synthesis of milk components in fresh mammary tissue from lactating animals for more than a few hours in vitro. While the rate of lactose synthesis and secretion under these conditions can be sustained in the short-term, a decline in lactose synthesis thereafter likely reflects, at least in part, the high metabolic rate of MEC. For example, when mammary tissue was isolated from lactating guinea pigs, half of the lactose present in the tissue was released into the culture medium within $5 \mathrm{~min}$. Following a washout phase, lactose secretion into the medium was then constant for up to $2.5 \mathrm{~h}$, during which time the release of lactose was 2-3 mg/g tissue/h [27]. After $48 \mathrm{~h}$ however, $C S N 2$ and $L A L B A$ mRNA and protein levels in mammary tissue and MEC decreased precipitously, even in the presence of PRL, INS, and GC [23, 24, 28].

Despite the limitations of these in vitro systems, they have certainly provided valuable insight into the hormonal regulation of LALBA and B4GALT1 gene and protein expression, as outlined in Fig. 1. In considering this summary, one should separately appreciate that the regulation of $L A L B A$ and B4GALT1 expression by hormones in vivo may well differ from that in vitro given the presence of a potential myriad of physiologic influences including blood flow, nutrient supply, and varying hydrostatic and osmotic pressures. Moreover, cultured mammary tissue responds differently to hormones depending on the reproductive state of the donor $[29,30]$. To assist the reader, we provide Supplementary File 1 that documents the culture conditions and outcome measures used in the literature that we describe hereafter.
Fig. 1 A schematic representation of the hormonal factors and mechanisms that regulate $\alpha$-lactalbumin (LALBA) transcription. The positive regulators of LALBA transcription are prolactin (PRL) and insulin (INS). Progesterone $(\mathrm{P})$ is a negative regulator of LALBA transcription. Thyroid hormone (T3), estrogen (E), glucocorticoids (GC), and epidermal growth factor (EGF) have variable effects on LALBA transcription that are species- or dose-dependent. Signaling occurs via intermediates including mammalian target of rapamycin (mTOR), phosphatidylinositol 3-kinase (PI3K), and phosphorylated signal transducer and activator of transcription 5 (pSTAT5)
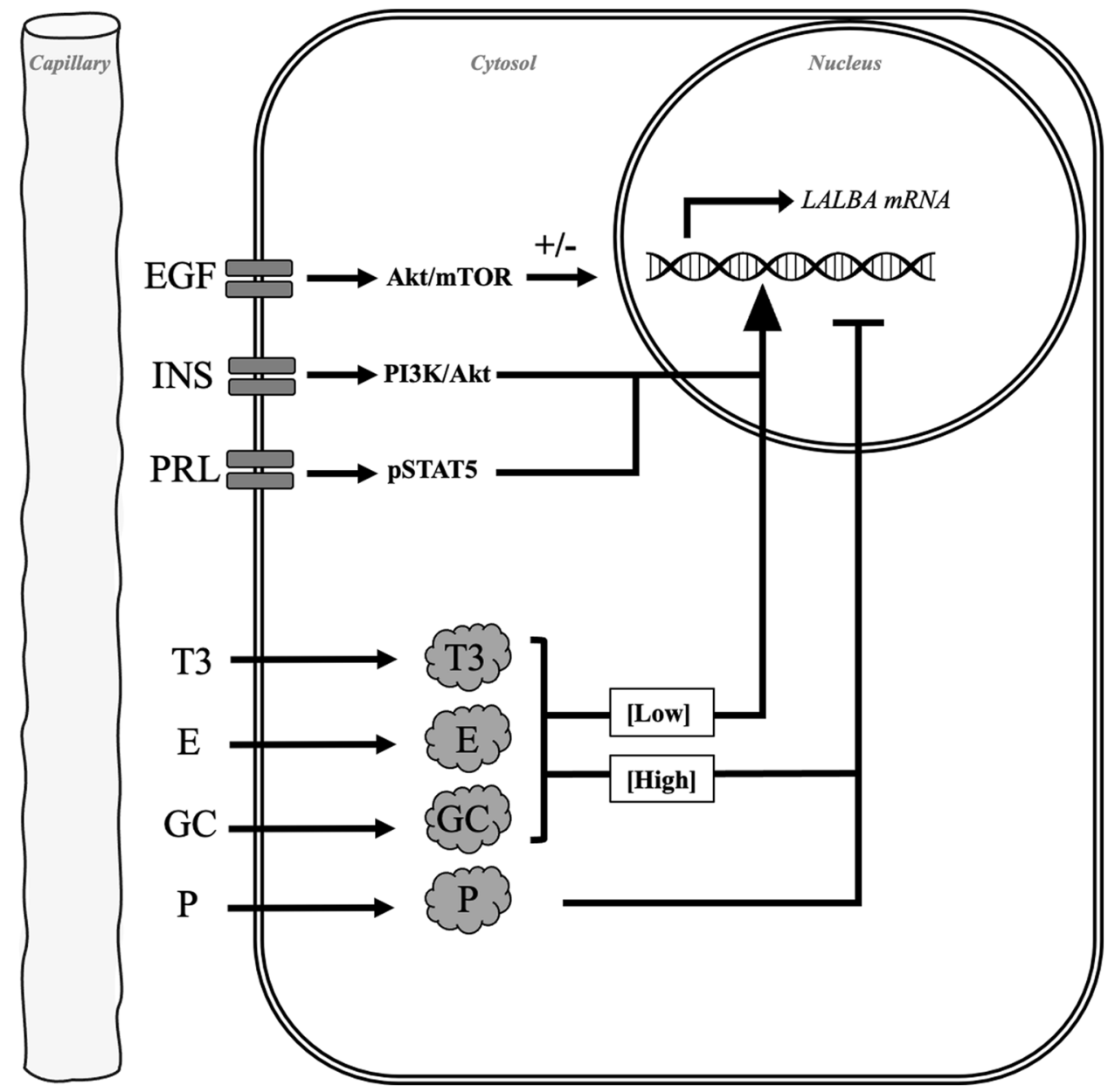


\section{Prolactin}

There is a clear requirement for PRL during the initiation of lactose and LALBA synthesis in most mammals, an effect that is most pronounced during the preparation for secretory activation. For example, in humans, plasma PRL levels peaked immediately after parturition, then fell to 50 to $100 \mathrm{ng} / \mathrm{ml}$ unless stimulated by suckling or pumping [44]. This transient elevation of plasma PRL levels was associated with a 3.5 -fold increase in $L A L B A$ mRNA in the milk fat globule membrane after $6 \mathrm{~h}$ [45]. In a range of species including non-pregnant humans and non-human primates, the synthesis of lactose alongside milk secretion can also be induced by exogenous estrogen $(\mathrm{E})$ and progesterone $(\mathrm{P})$ combined with a PRL-secretagogue [31-33]. Lactose synthesis was also induced in pseudopregnant mares and rabbits treated with a PRL-secretagogue or recombinant PRL, respectively. By contrast, endogenous PRL was sufficient to induce lactose synthesis in pseudopregnant heifers and goats [34-37]. Exposure of pregnant gilts to the PRL-secretagogue domperidone in late pregnancy also tended to increase the abundance of $L A L B A$ mRNA in biopsied mammary tissue by day 2 postpartum [38].

The effect of PRL on lactose synthesis during established lactation is less pronounced. Domperidone administered to lactating dairy cows did not promote lactose synthesis [39, 40], while milk lactose content was increased in lactating dogs treated with the PRL-secretagogue, metoclopramide, during the first week of lactation [41]. Both domperidone and metoclopramide are prescribed to increase milk production in humans although the quality of evidence supporting their effectiveness is low [42]. Administering recombinant PRL to lactating humans with PRL deficiency or to those pumping for their premature infants increased milk lactose content from 53 to $63 \mathrm{mg} / \mathrm{ml}$, and the concentration of neutral and acidic oligosaccharides doubled without affecting milk fat or protein content [43].

The positive effect of PRL on lactose synthesis occurs primarily at the level of $L A L B A$ and $B 4 G A L T 1$ transcription, where PRL first binds the PRL receptor to activate the interconnected Janus kinase 2/Signal transducer and activator of transcription 5 (STAT5) and phosphatidylinositol 3-kinase/Akt signaling pathways (Fig. 1). Phosphorylated STAT5 then binds other transcription factors such as the GC receptor (GR) prior to recruitment to promoter and enhancer regions of milk protein genes [46-48]. The critical role of PRL-induced signaling in lactose synthesis is highlighted by the fact that lactating mice with a conditional deletion of STAT5 within their mammary glands had decreased expression of $L A L B A$, but not CSN2 [49].

It is worth highlighting that the stimulatory effect of PRL on LALBA synthesis occurs in concert with other lactogenic hormones, specifically GC, INS, and T3. The synthesis of CSN2 and lipid in mammary explants from midpregnant mice and rats required PRL [50, 51]. Whereas LALBA could also be synthesized by explants cultured in a medium supplemented with only INS and GC, its synthesis was delayed by $24 \mathrm{~h}$ in the absence of PRL [52]. Similarly, in multi-week cultures of MEC from virgin and pregnant rats, the combination of INS and GC also stimulated LALBA synthesis, albeit to levels that were 18 -fold lower than those achieved by the combination of INS, GC, and PRL [22]. Likewise, the synthesis of LALBA in mammary explants from pregnant pigs was induced by PRL alone in a dose-dependent manner, while maximal LALBA synthesis required the combination of PRL, INS and GC [53].

The concentration of PRL required for maximal induction of LALBA synthesis in vitro also depends on the dose of GC, an effect that seems to be species-specific. Maximal LALBA synthesis by mammary explants from midpregnant rats occurred in the presence of a low concentration of GC $(10 \mathrm{ng} / \mathrm{ml})$ added to medium containing INS along with supraphysiologic levels of PRL $(5 \mu \mathrm{g} / \mathrm{ml})$. By contrast, when explants were cultured with a higher concentration of GC and PRL, as found in rats during late pregnancy $(40 \mathrm{ng} / \mathrm{ml}$ and $1 \mathrm{ug} / \mathrm{ml}$, respectively), the synthesis of LALBA was similar in the presence or absence of PRL [54]. The induction of LALBA by PRL in mammary tissue from midpregnant rabbits was enhanced by supplemental INS, but not GC [55].

Not surprisingly, an additional determinant of the extent to which LALBA synthesis responds to PRL is the reproductive state of the animal. Explants from postmenopausal humans required supraphysiologic concentrations of PRL $(20 \mu \mathrm{g} / \mathrm{ml})$ to initiate lactose synthesis, whereas a lower concentration $(2 \mu \mathrm{g} / \mathrm{ml})$ of PRL was required for the same response by explants from premenopausal individuals [29]. Likewise, induction of lactose synthase (LS) activity in mammary explants from virgin mice required either more time, or supraphysiologic concentrations of INS, PRL, and $\mathrm{GC}$, to reach a short-lived peak in activity relative to the times and concentrations required for explants from pregnant or parous mice. When PRL, GC, and INS were added to mammary explants from parous mice, the $\mathrm{ED}_{50}$ of these hormones that was required to induce LS activity was much lower than the $\mathrm{ED}_{50}$ for CSN2, implying that parity conferred a lower threshold for hormone-induced activation of LS [56].

The in vitro sensitivity of B4GALT1 levels to PRL matches changes in the concentration of B4GALT1 and PRL around the onset of lactose synthesis in vivo, and consistently differs from that for LALBA. When PRL was added to mammary explants from midpregnant mice and rats, lactose synthesis first increased after 4 to $8 \mathrm{~h}$ [54, 57]. By contrast, LALBA activity in mammary explants from midpregnant mice increased after $18 \mathrm{~h}[57,58]$. The activity of B4GALT1 and LS in explants from midpregnant mice 
reached a maximum after $3 \mathrm{~d}$ in culture, concomitant with the secretion of lactose into the medium, whereas LALBA activity continued to rise until it peaked on day 6 of culture, by which time the secretion of lactose had decreased to its nadir and the activity of B4GALT1 and LS was low [57, 58]. In a similar way, PRL was only able to induce a constant, linear rate of LALBA production in mammary explants from midpregnant rabbits after a 1-2 day lag [55].

We should point out that this apparent asynchronous induction of B4GALT1 and LALBA by PRL in mammary explants from midpregnant mice should be interpreted with caution. Specifically, at a physiologic concentration of PRL $(50 \mathrm{ng} / \mathrm{ml})$, the upregulation of B4GALT1 and LALBA in response to PRL were comparable [59]. Furthermore, other experimental conditions, such as the GC concentration, could explain a twofold greater induction of B4GALT1 by PRL, given that a high GC dose (5 ug/ml) was later found to specifically inhibit LALBA synthesis [60].

In summary, while PRL clearly directs the upregulation and maintenance of lactose synthesis, there are undoubted species- and concentration-specific differences in how PRL regulates $L A L B A$ expression, as well as how it cooperates with other hormones such as INS and GC. Some of these mechanisms still lack resolution. Moreover, there are still gaps in our understanding of how downstream effectors of PRL signaling cascades, in concert with other hormoneregulated pathways, regulate the expression of $\angle A L B A$ and $B 4 G A L T 1$ at the genomic level.

\section{Thyroid Hormone}

The ability of thyroid hormones to regulate lactose and milk production has been the subject of inconsistent investigation over several decades. Oral or intranasal thyroid hormone releasing hormone (TRH) administered to breastfeeding individuals for 4 weeks postpartum increased PRL secretion, milk production, and in some cases milk lactose content without a change in milk protein or fat content [61-64]. The greatest positive impact of TRH on milk production and lactose content was among those with insufficient milk production who received TRH in the first week postpartum [61-64]. Conversely, lactation failure can be an early clinical manifestation of both hyper- and hypothyroidism [65].

The effect of hypo- or hyperthyroidism on lactose content in other species is less clear. Administering thyroxine (T4) to lactating cows increased daily lactose yield by $25 \%$ and milk lactose content from 52 to $54 \mathrm{mg} / \mathrm{ml}[66,67]$. Even though $\mathrm{T} 4$ is essential for the galactopoietic effects of PRL in mice [68], there is limited data to support whether exogenous T4 affects their milk lactose content. The induction of hypo- and hyperthyroidism during lactation variably affected lactose synthesis in rats $[69,70]$, where hypothyroidism lowered the milk lactose concentration on day 15 of lactation (L(15)), but was without effect on $\mathrm{L}(1)$ or $\mathrm{L}(21)$ [71].

Combined lines of evidence suggest that the positive effects of triiodothyronine (T3) or T4 on lactose synthesis are species-specific and occur through a direct effect on LALBA transcription. For example, adding T3 or T4 to cultured primary MEC from virgin or midpregnant rats did not stimulate LALBA synthesis [22], whereas others recorded a clear stimulatory effect of T3 on LALBA and lactose synthesis in explants of mammary tissue from mice $[69,70]$. The level of $L A L B A$ mRNA and protein increased twofold in mammary tissue from midpregnant mice in response to T3, whereas levels of mRNA for B4GALT1, CSN2 content, total RNA, and total protein synthesis were unaffected [72, 73]. Whether T3 increased LALBA synthesis by exclusively stimulating transcription or extending the half-life of the LALBA mRNA transcript was not resolved [74].

One additional consideration is that $\mathrm{T} 3$ may modulate the actions of other hormones on MEC. Adding PRL to culture medium containing INS, GC, and T3 increased $L A L B A$ expression in murine explants by $40 \%$ above the level measured in cultures without $\mathrm{T} 3$ [72]. Whereas mammary tissue from virgin and midpregnant mice typically required supraphysiologic doses of INS, GC, and PRL over three days to induce LS activity, supplemental T3 or T4 reduced the necessary dose of INS, GC, and PRL to physiological levels, and increased lactose synthesis threefold [56, 72]. Over a range of concentrations, the L-forms of $\mathrm{T} 3$ and $\mathrm{T} 4$ were most stimulatory for LALBA synthesis, where the threshold for the induction of LALBA synthesis by L-T3 $\left(10^{-10} \mathrm{M}\right)$ was lower than for L-T4 $\left(10^{-8} \mathrm{M}\right)$ [72].

The regulation of lactose synthesis by thyroid hormones spans multiple levels and physiologic states and warrants continued investigation. In particular, the role of thyroid hormones in lactose synthesis is undoubtedly relevant for breastfeeding humans with thyroid disorders and clinical conditions involving metabolic dysregulation, such as obesity, as well as for high-producing dairy livestock that are prone to extreme negative energy balance. These questions also extend to the molecular level, where the action(s) of thyroid hormones on various milk protein genes, including LALBA, remain to be defined.

\section{Progesterone (P)}

The role for $\mathrm{P}$ during the initiation of lactation is clear, where its circulating levels must decrease to initiate the onset of copious lactose synthesis during secretory activation. This critical role for $\mathrm{P}$ is highlighted in postpartum humans with retained placental fragments, where secretory activation was delayed until the P-secreting placental tissue was removed $[75,76]$. The best demonstration of a mechanistic relationship between circulating $\mathrm{P}$ and the onset of 
secretory activation is the rapid induction of B4GALT1 and LALBA activity in mammary tissue homogenates isolated from rats following ovariectomy-induced depletion of $\mathrm{P}$ on day 19 of gestation [77]. This induction could be reversed when P was administered immediately after ovariectomy, whereas its inhibitory effect was less following administration 12 or $24 \mathrm{~h}$ later [77]. The effect of bilateral ovariectomy on total lactose content in mammary tissue was also evident in late-gestation rats 24 to $48 \mathrm{~h}$ after surgery, a response that was greater in rats ovariectomized later in gestation [78].

The mechanism by which $\mathrm{P}$ inhibits lactose synthesis primarily involves its repression of $L A L B A$ transcription. Notably, this repression is most pronounced in mammary tissue from preparturient animals and is species-specific. For example, whereas P inhibited LALBA synthesis in mammary explants from virgin and early- to mid-pregnant mice, the same dose only inhibited LALBA production by $50 \%$ in mammary tissue from late-pregnant rats. In lactating rats the effect of $\mathrm{P}$ on LALBA synthesis was less, where a 1000-fold higher concentration of $P$ was required to decrease LALBA content in mammary tissue from lactating versus non-lactating rats [30]. By contrast to these findings for rats, the P-induced suppression of $L A L B A$ in explants from lactating, non-pregnant cows was more sensitive than was $C S N 2$ or genes required for fat synthesis. For example, only $15 \mu \mathrm{M}$ of $\mathrm{P}$ was required to inhibit $L A L B A$ transcription, whereas doses $>30 \mu \mathrm{M}$ were required to inhibit CSN2 transcription [79].

\section{Estrogens (E)}

There are several indications that $\mathrm{E}$ can inhibit lactose synthesis during established lactation. Birth control pills delivering $\mathrm{E}+\mathrm{P}$ decreased the content of LALBA in breast milk and overall milk production, although the volumetric decrease was still within the normal range of output [80]. Birth control pills containing $\mathrm{E}$ are also used to treat hyperlactation in humans, although the mechanism is undefined [81]. In lactating cows, a single dose of synthetic E accelerated mammary involution coincident with a reduced concentration of LALBA and lactose in milk following final milk removal $[82,83]$. In a similar way, a high concentration $(30 \mu \mathrm{M})$ of $17-\beta$-estradiol inhibited LALBA secretion by mammary explants from lactating cows by $35-45 \%$ [79]. When high doses of $\mathrm{E}$ were administered to goats during midlactation, they demonstrated a varied response in milk composition, with most having a progressive decline in milk yield. Among those goats, two animals had complete suppression of milk and lactose production within four days [84].

Beyond these responses, there is also evidence for a biphasic effect of $E$ concentrations on LALBA and lactose synthesis. For example, a low dose $(50 \mu \mathrm{g})$ of synthetic
E increased milk production in ewes in late lactation whereas a high dose $(5 \mathrm{mg})$ was inhibitory and decreased milk lactose content from 60 to $45 \mathrm{mg} / \mathrm{ml}$ [85]. In explants from midpregnant mice, low concentrations ( 1 or $5 \mathrm{ng}$ / $\mathrm{ml}$ ) of $17-\beta$-estradiol, estrone, diethylstilbestrone, but not 17 - $\alpha$-estradiol, stimulated LS and B4GALT1 activity, whereas a high concentration $(5 \mu \mathrm{g} / \mathrm{ml})$ of $17-\beta$-estradiol was inhibitory for LS, but not B4GALT1, activity. The full effect of $\mathrm{E}$ on LS activity in these data was only evident $24 \mathrm{~h}$ after supplementation with T3 and physiologic levels of PRL or human placental lactogen. Even though the mechanism by which LALBA synthesis is stimulated or inhibited in response to $\mathrm{E}$ is unknown, the effect of $\mathrm{E}$ on LALBA synthesis in mammary explants was most apparent when the medium was also supplemented with a low, physiologic concentration of PRL $[59,86]$.

Taken together, different lines of evidence support that $\mathrm{E}$ and $\mathrm{P}$ can modulate lactose synthesis during the onset of secretory activation and into established lactation. The inhibition of lactose synthesis through the P-induced downregulation of $L A L B A$ expression is most evident during pregnancy and in the hours immediately following the removal of the P-secreting tissue. Questions linger as to whether P remains inhibitory for lactose synthesis during lactation. The fact that different levels of E biphasically regulate $L A L B A$ expression is noteworthy and shares similarities with the biphasic response to different levels of GC we outline below. The relationship between E, T3, PRL, and $\mathrm{P}$ in the regulation of $L A L B A$ described thus far underscores the importance of developing bona fide ex vivo and in vivo systems for the study of lactose synthesis and milk production.

\section{Glucocorticoids (GC)}

The increasing secretion of cortisol by the adrenal glands during gestation prepares MEC for the onset of copious milk secretion. In fact, GC facilitate an array of cytological changes in MEC including the synthesis of rough endoplasmic reticulum, tight junction closure, increased PRL receptor (PRLR) expression, and regulation of milk protein gene expression [87]. In these ways, mammary explants from midpregnant mice entered a secretory state when exposed to hydrocortisone, corticosterone, or aldosterone at 1 or $5 \mu \mathrm{g} / \mathrm{ml}$, while deoxycorticosterone was ineffective [88]. The effects of GC are also clearly evident when they are administered to pregnant animals, which invokes secretory activation with or without premature parturition, depending on the species [89-93]. As a case in point, milk lactose concentration and udder distension were increased in multigravid goats within $24 \mathrm{~h}$ of a second dose of adrenocorticotropic hormone. Thereafter, the milk lactose content during the rest of the pregnancy did not return to pre-treatment levels, but instead remained elevated at levels seen in mature 
milk [93]. In a similar way, administering GC to pregnant humans induced secretory activation despite the high circulating level of $\mathrm{P}$, as was evidenced by breast engorgement and increased excretion of urinary lactose [92, 94]. Exogenous GC had less of an effect on the induction of lactose synthesis in humans further along in their pregnancy [91]. Interestingly, ewes that underwent precocious secretory activation in response to exogenous GC subsequently produced less milk with a lower lactose content $[90,91]$.

There is also a clear impact of GC on milk production during established lactation. Such a relationship is most clear for plasma cortisol, which is negatively associated with milk lactose concentration. However, the association between the concentration of cortisol in milk and its lactose content is less consistent [95-97]. This effect of GC on lactose synthesis, including the effect of exogenous GC, can be revealed in different models and states. For example, lactating humans who received an injection of exogenous GC for musculoskeletal pain had complete or near complete suppression of milk production within one day [98, 99]. In the same way, synthetic GC administered to lactating cows reduced milk lactose concentration from 46 to $43 \mathrm{mg} / \mathrm{ml}$ within $24 \mathrm{~h}$ of treatment, concomitant with a decrease in milk yield of approximately $10 \mathrm{~kg} / \mathrm{d}$ [100]. Rat and mouse pups whose dams received daily injections of cortisone had retarded growth within $24 \mathrm{~h}$ of treatment [101, 102]. Likewise, hydrocortisone administered to rat dams for the first 15 $\mathrm{d}$ of lactation decreased total protein and lactose concentration in milk [103].

Another example of how GC potentially modify the synthesis of lactose can be recorded during times of stress, where both lactose and milk production decrease in association with a dysregulated hypothalamic-pituitary-adrenal axis and increased cortisol secretion [104]. Within $46 \mathrm{~h}$ of exposing lactating ewes to a stressful event, lactose content and milk yield decreased, whereas milk fat and protein concentration increased [105]. Similar responses were recorded in dairy cows exposed to transportation stress [106]. Intriguingly, goats did not demonstrate a decrease in lactose synthesis or milk yield following exposure to a stressful event [107-109]. From these data across a range of species it is clear that endogenous GC and high doses of exogenous GC can negatively impact milk production and lactose synthesis.

A primary mechanism underlying the negative effect of GC on milk output likely involves the suppression of LALBA synthesis (Fig. 1), an effect that varies depending on the developmental and lactational stage of the animal as well as the concentration and type of GC. Notably, GC exerted a differential effect on the expression of $L A L B A$ versus $C S N 2$ and $B 4 G A L T 1$, where low concentrations of GC stimulated $\angle A L B A$ expression in explants from midpregnant rats and mice, while high concentrations suppressed LALBA synthesis $[24,110,111]$. By contrast, the synthesis of B4GALT1 and CSN2 increased in response to GC in a dose-dependent manner $[112,113]$. As a case in point, maximal CSN2 synthesis occurred in response to hydrocortisone concentrations that were 200 times greater than those required for maximal LALBA synthesis $[110,112]$. Lactose synthesis within mammary organoids from mice also responded to increasing concentrations of GC in a biphasic manner [24, 114]. For mammary organoids from lactating mice cultured on floating collagen gels, a low concentration of cortisol $(0.03 \mu \mathrm{M})$ was more stimulatory for LALBA synthesis than a high concentration $(3 \mu \mathrm{M})[115,116]$. Similarly, in mammary explants isolated from lactating cows, deoxycorticosterone at $30 \mu \mathrm{M}$ inhibited LALBA secretion by $35-45 \%$ without affecting glucose uptake [79].

While most of these studies were conducted using tissue or cells from mice, we should point out that other physiological factors likely impact the overall response to GC. For example, the biphasic effect of GC on LALBA synthesis in mammary explants isolated from virgin and midpregnant mice may well not exist for explants isolated from lactating mice [28, 30, 79, 117-119]. Furthermore, the biphasic dose response by LALBA to GC was not observed in a longterm culture system using MEC isolated from either virgin or midpregnant rats [120]. Across these types of experiments there was also variation between individual animals in the amount of LALBA synthesized in response to low, stimulatory concentrations of GC when using mammary explants isolated from late pregnant and lactating rats $[28$, 30]. These types of variation likely reflect a combination of factors including heterogeneity within the mammary gland, as highlighted above, and interactions with other factors, as outlined below.

Not surprisingly, the effects of GC on LALBA synthesis in vitro are modulated by interactions with other factors including PRL, prostaglandins (PG), T3/T4, or spermidine. One such example is the presence of GC that decreases the dose of PRL required for maximal LALBA synthesis. Specifically, when an inhibitory high concentration of GC was added to cultures along with a lower concentration of PRL $(0.5 \mu \mathrm{g} / \mathrm{ml})$ and INS, the GC-induced suppression of LALBA synthesis was not as pronounced as it was in the presence of a higher concentration of PRL (5 $\mu \mathrm{g} / \mathrm{ml})$ [110]. A similar situation exists for PG, where it reversed the negative effect of high concentrations of GC on LALBA synthesis in cultures of mammary explants from midpregnant mice; the $\mathrm{ED}_{50}$ for PGE2, PGF2 $\alpha, \mathrm{PGA} 2$, and PGB2 to overcome the inhibitory effect of GC were $0.4,0.4,10$, and $10 \mu \mathrm{M}$, respectively [121]. Notably, PG could not stimulate LALBA synthesis after the GC-induced inhibition was reversed [122]. Unlike PG, T3 not only prevented the negative effect of a high GC concentration on LALBA synthesis, but also stimulated the synthesis of LALBA [73, 122]. Lastly, the production of LALBA in mammary explants 
from midpregnant mice could be induced without GC when spermidine was added alongside PRL and INS at concentrations as low as $0.4 \mathrm{mM}$ [123]. By contrast, the synthesis of LALBA by explants from midpregnant rabbits required only INS and PRL, but not spermidine or GC, whereas maximal LALBA synthesis in explants from midpregnant rats required the combination of INS, PRL, GC, and spermidine [124].

As outlined above, a role for GC in the regulation of milk synthesis has been dissected extensively in vitro, particularly with regards to its role as a co-regulator of milk protein synthesis. Surprisingly, the extent to which this hormonal modulation occurs in vivo, and the relevance of these findings to lactation and their potential role during environmental exposures such as stress and following the therapeutic use of GC in human and veterinary medicine, remains underinvestigated. Of particular relevance to these scenarios is the biphasic regulation of $L A L B A$ expression by GC, where its negative effect at high levels is likely through its direct effect on lactose and LALBA synthesis.

\section{Insulin (INS)}

Many in vitro studies have cemented the essential role of INS for $L A L B A$ expression at the level of the mammary epithelium, consistent with its widely-recognized role in stimulating various milk protein genes (Fig. 1) in concert with the effects of PRL and GC. For example, the expression of three genes involved in lactose synthesis, namely $L A L B A, U G P 2$, and $G L U T 1$, increased in response to INS added to cultured mammary tissue from midpregnant mice [125]. Likewise, the expression of LALBA mRNA in mammary explants from late-pregnant cows increased tenfold when INS was added to the culture medium [126].

Intriguingly, these robust effects of INS on lactose synthesis in vitro do not translate to a clear indication that plasma INS modulates lactose synthesis in vivo. This conclusion aligns with the widespread demonstration that glucose uptake by the mammary glands is INS-independent, consistent with the well-established fact that INS-dependent GLUT4 is absent in mammary tissue [127, 128]. Infusion of INS also did not affect the arteriovenous difference for glucose across the mammary glands of goats, cows, or sheep. In a similar way, milk production and lactose synthesis by cows and sheep was unchanged in response to acute or chronic elevations of plasma INS during a glucose clamp experiment $[129,130]$. All these findings are consistent with the fact that a single dose of slow-release INS during the first week postpartum did not affect milk lactose output or milk yield from dairy cows [131].

These differences between the effects of INS on lactose synthesis in vitro and in vivo highlight how considerable gaps still remain in our understanding of both INS action and the regulation of lactose synthesis. Beyond the global role for INS in homeostasis and nutrient partitioning and its dysregulation across a range of conditions, there are still a number of questions that remain regarding its role in support of milk production.

\section{B2-adrenergic Receptors and their Downstream Effectors}

It is also worth mentioning some of the early studies that examined the ability of signaling downstream of $\beta 2$-adrenergic receptors to regulate lactose synthesis (Fig. 1). Pregnant rats that received the $\beta 1$ - and $\beta 2$ - antagonist propranolol following the induction of secretory activation had a lower concentration of lactose in their mammary glands, whereas targeting the receptors pharmacologically using either prazosin (an $\alpha 1$ receptor antagonist) or metoprolol (a $\beta 1$ receptor antagonist) had no effect [132]. By contrast, epinephrine and isoproterenol ( $\beta$-adrenergic agonists) both inhibited the synthesis of lactose by cultured explants from lactating guinea pigs by $29 \%$ and $25 \%$, respectively [27]. These opposing effects of $\beta$-adrenergic receptor signaling on lactose synthesis, albeit in two different species and in different physiological states, further highlights the need for a comparative approach to defining the control mechanisms underlying lactose synthesis.

The $\beta 2$-adrenergic receptors are linked to the adenyl cyclase second messenger pathway (cAMP) and are regulated by PRL and ovarian hormones. The accumulation of LALBA within mammary explants from midpregnant mice decreased by $90 \%$ after supplementation with cAMP, whereas the CSN2 content decreased by only $35 \%$. Sodium butyrate, 3'AMP, 5'AMP, adenosine triphosphate, adenosine monophosphate, and guanosine cyclic monophosphate did not affect LALBA synthesis. The inhibitory effect of cAMP on LALBA and CSN2 production was also augmented when a phosphodiesterase inhibitor was present [133]. In a similar way, lactose synthesis by explants from midpregnant mice and lactating guinea pigs was reduced following the supplementation of cultures with cAMP and phosphodiesterase inhibitors [27, 134]. All these findings regarding the effects of $\beta 2$-adrenergic receptor activation warrant further investigation given the importance of the neuroendocrine system in stress management and the widelyappreciated negative impact of stress on lactation performance.

\section{Epidermal Growth Factor (EGF)}

While EGF plays a crucial role as a paracrine growth factor in the developing mammary glands, there is also strong evidence to support it having a suppressive effect during the onset of lactation. In this way, LALBA activity in cultured explants from midpregnant mice was inhibited by $40 \%$ when they were exposed to EGF [135], similar to the suppressive effect of EGF 
on cultured MEC from lactating mice [116]. Similarly, synthesis of LALBA in ewes, rabbits, and mice was suppressed by EGF in vivo or ex vivo, where ewes in early lactation that received intravenous murine EGF produced less milk with lower lactose content [136]. Likewise, EGF suppressed the induction of $L A L B A$ by PRL in cultured mammary explants from midpregnant rabbits. Interestingly, this inhibitory effect of EGF was reversed by a low concentration of cortisol that also stimulated LALBA synthesis, whereas corticosterone and aldosterone reversed the suppressive effect of EGF, but were not stimulatory [51]. For reasons that are not entirely clear, the situation in rats appears different, where EGF promoted LALBA synthesis by cultured mammary explants from virgin and midpregnant rats [137]. In keeping with this positive effect, EGF also blocked the inhibition of LALBA synthesis by $\mathrm{P}$ in mammary tissue from pregnant rats [137].

\section{Summary - Hormonal Regulation of LALBA and B4GALT1 Synthesis}

Taken together, it is perhaps not surprising that a milieu of hormones and their interactions can dramatically modulate lactose synthesis, which is achieved in a large part at the level of LALBA transcription. Many of these findings are based on some very detailed and thorough in vitro studies, particularly using mammary explants and relatively defined conditions. In our view, the physiological implications of these data are yet to be fully captured, whether that be for identifying ways to improve breastfeeding success, optimize milk production for dairy livestock, or support neonatal growth.

\section{The Genetic Regulation of Lactose Synthesis}

In the previous section we detailed the impact of endocrine signals on lactose synthesis, particularly through their ability to positively or negatively affect $L A L B A$ expression. The nature of this regulation is, of course, particularly relevant during reproductive progression, as well as during adverse states such as stress. However, the synthesis of lactose is also determined at the genetic level, which applies across a range of taxonomic groups. Here we summarize a range of genetic mechanisms that directly regulate, or are associated with, altered lactose synthesis across numerous species and systems, with a primary focus on the genetic regulation of LALBA and B4GALT1.

\section{Polymorphisms in Genes Outside the Lactose Synthesis Pathway}

The ability to screen for genetic polymorphisms in livestock including cattle, sheep, and horses has led to the identification of various genomic variants that are associated with measurable alterations in lactose output. In many cases, not surprisingly, these variants can be implicated in pathways underlying the synthesis of other major milk components including $\beta$-lactoglobulin [138-142], milk fat (1-acylglycerol-3-phosphate O-acyltransferase 6 and diacylglycerol O-acyltransferase 1) [143-145], lactotransferrin [146] and the caseins [146]. In other cases, polymorphisms are more directly implicated in the hormonal regulation of the synthesis of lactose or other milk components, as is the case for the leptin receptor [143, 147, 148], growth hormone [146], growth hormone receptor, PRL, and suppressor of cytokine signaling 3 [138-142], or glucocorticoid receptor DNA-binding factor-1 [146] genes. While associative, these types of analyses can inform genetic selection strategies in livestock, where similar data accompanied by lactation performance measures will undoubtedly reveal a better understanding of the genetic regulation of lactose synthesis in humans.

\section{Genetic Variation in B4GALT1 and its Impact on Lactose Synthesis}

The B4GALT genes are expressed by most cell types to support intracellular glycosylation. By contrast, B4GALT1 expression in MEC is tightly regulated during gestation and lactation to coordinate with, and support, lactose synthesis. Until mid-pregnancy, MEC transcribe a $4.1 \mathrm{~kb}$ B $4 G A L T 1$ mRNA with a 175 nucleotide 5 ' untranslated region (5' UTR), concurrent with binding of Sp1 immediately upstream of a transcription start site (TSS). Subsequently, during late-pregnancy and throughout lactation, specificity factor 1, nuclear factor 1/CCAAT box-binding transcription factor, and Apetala 2 bind a different region, either $\sim 200 \mathrm{bp}$ upstream or downstream from the same TSS, yielding a truncated $3.9 \mathrm{~kb}$ mRNA transcript. This $3.9 \mathrm{~kb}$ mRNA transcript has a shorter 5'UTR that lacks an extensive secondary structure and has increased translational efficiency $[1,149,150]$.

Several SNP exist within the bovine B4GALT1 gene. Among nine SNP, three were associated with lower lactose content in milk whereas three others were associated with higher lactose content. Consistent with the aforementioned modulation of B4GALT1 mRNAs, one of these SNP was in the TSS and directed the switch between the long and short form of the B4GALT1 5'UTR in association with the milk having a lower lactose content. Two SNP were present in the B4GALT1 catalytic domain and were associated with a higher lactose content in milk. While SNP also exist within the region of B4GALT1 that interacts with LALBA, none were significantly associated with milk composition or volume [151]. 


\section{Regulation of LALBA Gene Transcription}

Given the critical role of lactose across a broad range of mammals, it is not surprising that the genetic structure of $\angle A L B A$ is widely-conserved, including its exon-intron boundaries [152-157]. The first three exons of $L A L B A$ are homologous to the lysozyme gene, while the fourth is unique [152]. In a similar way, a comparative analysis of the regulatory factor binding sites located in the $L A L B A$ promoter in the bovine, caprine, human, murine, rat, and swine genomes revealed three conserved motifs (LA1, LA2, LA3) located in the proximal end of the promoter sequences that were distinct from motifs found in the promoters of other milk protein genes [158].

The pronounced change in LALBA mRNA abundance during pregnancy and into lactation highlights how tightly its expression is coordinated at the transcriptional level. The murine $L A L B A$ proximal promoter ( $2.5 \mathrm{~kb}$ upstream of the TSS) has an open chromatin structure across all reproductive states $[159,160]$. Surprisingly, the binding of only a few transcription factors to the LALBA promoter has been assessed. The LALBA gene in rats and humans, as well as their five casein genes, all share an nuclear factor 1 binding site in their proxmal promoter [161]. The promoters for mouse, rat, human, and bovine $L A L B A$, as well as the Ca-sensitive caseins and whey acidic protein, also have a conserved STAT5 binding site. Within the human $L A L B A$ promoter, these STAT5 binding sites are all proximal to steroid hormone binding sites [162, 163]. Additional repeated hexanucleotide sequences have also been identified in the human and rat $L A L B A$ promoter, although they do not resemble the consensus GR response element [153]. Consistent with this genomic landscape, both GR and pSTAT5 were bound to the murine LALBA promoter on days 1 and 10 of lactation [48]. Despite the fact that $\mathrm{P}$ clearly regulates lactose synthesis with the onset of lactation, it has not been established whether the LALBA promoter has a P receptor binding site in its 5'UTR [155]. Interestingly, the TATA, CCATT, GC response element boxes, and mammary gland-specific transcription factor sequences were not identified in a $500 \mathrm{bp}$ region upstream of the tammar wallaby $L A L B A$ coding sequence [164], perhaps reflecting the differential control of lactational output across developmental stage in this species.

In addition to regulation at the promoter, $L A L B A$ transcription is also influenced by its distal enhancer, which lies 1500 bp upstream of the bovine LALBA TSS [165]. This region is 75\% homologous to the CSN2 distal enhancer. While the CSN2 distal enhancer has consensus binding sites for pSTAT5 and C/EBP, the transcription factors that bind the putative $L A L B A$ enhancer are yet to be defined [166, 167], although GR and pSTAT5 were bound to the putative murine LALBA super-enhancer on $\mathrm{L}(1)$ and $\mathrm{L}(10)$ [48].
Superimposed on these transcriptional controls is an epigenetic landscape for the $L A L B A$ gene that is distinct from that for $C S N 2$ or whey acidic protein. In mice, the $L A L B A$ proximal promoter has an open chromatin structure across all reproductive states, which supports the notion that finetuning of $L A L B A$ transcription primarily occurs through the binding and tethering of transcription factor complexes to its proximal promoter [160]. The tailoring of an epigenetic environment in support of lactose synthesis is also illustrated by the fact that the different genes that contribute to lactose synthesis all consistently maintain the chromatin modifications they acquired during pregnancy and lactation. By contrast, the epigenetic modifications surrounding the CSN2 gene reverted to their pre-gestational state after involution [168].

\section{Genomic Variation and the Regulation of LALBA Function}

The considerable genetic variation that exists within the LALBA gene across species also offers potential insights to its core functional elements. At the nucleotide level, there is a multitude of SNP within both the 5'UTR and coding regions of the $L A L B A$ gene, although few have been analyzed for their association with milk yield or composition [165, 169-177]. At one extreme, a single SNP 15 bp away from the LALBA TSS in Holstein cows was associated with higher lactose content and milk yield, but lower fat and protein content, and was proposed to account for a 30-fold greater expression of LALBA in explants from Holstein versus Angus cows [171, 178, 179]. Intriguingly, the same SNP in Swedish Red and White cows did not affect milk lactose concentration [178]. In a similar way, an I/V substitution at amino acid 46, the site of LALBA glycosylation, did not affect LALBA or lactose concentration in human milk [170], and none of four SNP in the 5'UTR of the equine $L A L B A$ mRNA were associated with altered LALBA mRNA or protein expression [177]. Among Chinese Holstein dairy cows, a T1847C SNP in a noncoding region was associated with lower lactose content and yield, but not fat or protein content [180]. Nine SNP were identified in the 5'UTR and 3'UTR of the Sarda goat $L A L B A$ mRNA transcripts, of which two SNP (-368 and -163) located at apetala $2 \alpha$ and specific factor 1 transcription factor binding sites, respectively, were associated with lower milk lactose content [181].

What is perhaps even more enlightening is the genetic and associated phenotypic variation that exists within the LALBA gene across various marine mammals. The LALBA promoter in the Cape fur seal has a series of cis-acting mutations that results in the synthesis of a viscous, lactose-free milk with a high concentration of protein and fat [182]. In the California sea lion, the Antarctic fur seal, and the Cape fur seal, the LALBA TATA box has a T-G transversion (AAGAAA) in the third position that prevents binding of 
the TATA binding protein, thereby preventing transcription initiation. However, the introduction of a STAT5 binding site and correction of the transversion in the TATA box in the LALBA promoter for the Cape fur seal did not activate gene transcription, suggesting that other mutations, like the disruption in the fourth exon found in the otariid LALBA gene, also contribute to the inability of the Cape Fur seal to synthesize LALBA and lactose [182, 183]. Interestingly, the Atlantic walrus has a 7 bp deletion that leads to a frame shift in exon 4 of $L A L B A$, which translates to a longer 176 amino acid protein that is incapable of participating in lactose synthesis [183].

Taken together, these multiple layers of genomic and transcriptional regulation highlight how the genetic basis of lactose output has evolved as a tightly-coordinated program, while also being semi-independent from the expression of other milk proteins. There is also a great deal that remains to be learned about how these transcriptional controls are regulated and coordinated, not only across the lactational cycle, but also within individual cells and regions within the gland. Regardless, the combination of these insights points to a vast opportunity to harness and optimize these regulatory mechanisms, whether it be to manipulate milk composition or to improve the milk production potential in humans and livestock.

\section{Post-translational Control of LALBA}

The LALBA mRNA and protein undergo significant posttranscriptional and post-translational regulation and processing [184]. The primary site of LALBA glycosylation surrounds the N-glycosylation consensus sequence at Asn-45 $[185,186]$, where glycosylation has been proposed to suppress the secretion of LALBA to allow for quality control at the level of the endoplasmic reticulum [187]. How the extent or nature of LALBA glycosylation impacts lactose synthesis and milk output is unclear, as we alluded to previously [1]. Introducing an Asn45Asp substitution into the water buffalo LALBA rendered it incapable of being glycosylated, although the associated milk composition was unchanged [186]. Goat LALBA contains two glycosylated residues at amino acids 45 and 74, yielding either an unglycosylated, singly- or doubly-glycosylated molecule [187]. Secretion of goat LALBA in a yeast culture system was suppressed when the number of $\mathrm{N}$-linked glycosylation sites was increased to three, whereas its secretion was highest when amino acid 45 was mutated and N-linked glycosylation was lost [187]. Certainly, there are physiological contexts where glycosylation of LALBA also varies. For example, adding EGF to explants from midpregnant rats cultured with INS, PRL, and GC decreased the synthesis of glycosylated LALBA by approximately $30 \%$, such that the ratio of the two forms was 1:1 [188]. Conversely, supplementing cultures with T3 increased the abundance of glycosylated LALBA, whereas only non-glycosylated LALBA was produced by explants cultured in its absence [189].

\section{Lessons from Transgenic Animals Carrying an Exogenous LALBA Sequence}

Transgenesis has served as a particularly innovative and insightful means to study and manipulate different aspects of the lactose synthesis pathway in animal models. We have elected to review those studies here, rather than in the respective sections above, because it is important to recognize that the context of situations like overexpression, heterologous systems, and altered physiological function can lead to different outcomes that may cloud any interpretations.

For some time a standing assumption was that the $L A L B A$ proximal promoter was sufficient to direct maximum gene expression, whereas optimal transcription of $C S N 2$ required its distal enhancer elements $[165,190]$. In early experiments, only short $(<1 \mathrm{~kb}) L A L B A$ promoter fragments were used to direct transgene expression in mice, based on the knowledge that many important, albeit undefined, cis-acting elements are located between positions -477 and -220 [191]. Transgenic mice with a longer 5' $L A L B A$ promoter fragment expressed bovine LALBA at approximately 1000 times higher concentrations than those harboring a shorter 5' fragment. While the resultant milk lactose content was not measured, transgenic mice that expressed higher quantities of bovine LALBA produced viscous milk [192]. When a $2 \mathrm{~kb} L A L B A$ promoter was used to direct the expression of bovine CSN2 in transgenic mice, the MEC underwent premature involution in association with more production of CSN2 and a viscous milk, similar to that described in $L A L B A$ knock out mice [193]. These findings contrasted with the phenotype of transgenic mice expressing caprine $\beta$-casein under the control of the caprine $\kappa$-casein promoter that maintained their milk production and composition. The authors proposed that the bovine LALBA 5'UTR sequestered transcription factors from the endogenous LALBA promoter, suppressing the production of LALBA and lactose [190, 193, 194].

Interestingly, a range of transgenic animal models has supported the general conclusion that overexpression of exogenous LALBA differently affects milk lactose content across species. Transgenic mice overexpressing human $L A L B A$ from a construct containing a $0.77 \mathrm{~kb} 5$ ' fragment expressed the exogenous gene and protein at levels 14-fold greater than those for endogenous LALBA, without any effect on milk lactose content [195]. Transgenic sows bearing a bovine $L A L B A$ construct that included $2 \mathrm{~kb}$ of upstream sequence produced $20-50 \%$ more milk that had a higher milk lactose content and lower total solids, protein, and fat concentration than control animals [50]. This positive 
effect of bovine $L A L B A$ on milk composition was still apparent in the second lactation, where sows produced twice the amount of bovine LALBA in colostrum and milk versus during their first lactation [196, 197]. The concentration of bovine LALBA in transgenic mice varied tenfold between mice from the same transgenic line, suggesting that variation in the expression of exogenous LALBA was not just due to random integration of the transgene into the genome [192]. Likewise, the amount of human LALBA secreted into milk from transgenic cows varied from 0.17 to $1.56 \mathrm{mg} /$ $\mathrm{ml}$ [198]. Transgenic cows only produced unglycosylated human LALBA, whereas transgenic mice produced bovine LALBA that was glycosylated at levels similar to those found in bovine milk $[198,199]$. Transgenic cows expressing human $L A L B A$ also expressed 43 unique proteins in the milk fat globule membrane without any apparent effect on the biology of milk synthesis [200].

These various animal experiments highlight the potential importance of regulatory elements within the 5' UTR of the $\angle A L B A$ gene. Combined with the aforementioned transcriptional regulatory mechanisms, it becomes clear that there is a host of conserved as well as species-specific regulatory elements that control and optimize LALBA transcription. These findings also set the stage for future, more precise genetic modification strategies, such as those that can be edited using CRISPR/Cas9.

\section{Conclusion}

In this review we focused on defining the range of control points that regulate lactose synthesis, particularly at the endocrine and genetic levels. As we outlined above, combinations of intracellular and intramammary regulatory factors (Fig. 1) are among the primary control points for lactose synthesis, more so than extramammary conditions like plasma glucose and blood flow. Nevertheless, dysregulation in the delivery of plasma glucose is inextricably tied to lactational output and is associated with stress and metabolic syndromes, such as obesity and diabetes mellitus. Plasma glucose availability and its uptake by the mammary gland for lactose synthesis is also modulated by the negative effect of fasting, caloric deprivation, and dietary carbohydrate restriction. Moving forward, one consideration is that lactating rodents may not be the best translational model for the study of food deprivation on lactose synthesis given their response is much more pronounced than that for lactating humans, and that they do not recapitulate the lower plasma glucose levels seen in lactating ruminants.

In considering the crucial role for, and regulation of, lactose, there is no doubt that its synthesis and function(s) are a centerpiece for a range of emerging scientific concepts and global issues. Lactose plays a vital role in the movement of water which is a major component in dairy products worldwide. All these processes, as well as the survival of threatened species across a warming planet, depend on the movement of ever-scarcer water that is facilitated by the actions of lactose. At the same time, LALBA and lactose are critical for infant nutrition, as sources of protein and carbohydrate, respectively. Lactose also serves as the building block for a range of oligosaccharides that we now recognize have critical roles in regulating infant growth and development via the gastrointestinal microbiome.

With advances in genetic engineering and selection, there may also be ongoing opportunities to manipulate milk composition by targeting the lactose synthesis pathway. As a starting point, genetic mutations in the $L A L B A$ promoter that directly lead to a reduction in lactose synthesis need to be defined. Furthermore, the transcriptional regulators within the promoter and enhancer regions of the $L A L B A$ gene require better resolution as a way to screen and riskstratify patients by their need for additional lactation support services or tailored therapeutic regimens. Many of these questions can now be pursued using mainstream sequencing technologies and non-invasive methods of studying the transcriptome from cells and the milk fat globule in milk. Special attention should also be placed on the species-specific effects of PRL, EGF, and thyroid hormone and the biphasic regulation of LALBA by $\mathrm{E}$ and GC, given that both steroids are involved in endogenous physiological responses and are common pharmacologic agents used in human and veterinary medicine. All these questions become additionally challenging to study given that there is an ongoing absence of in vitro models that mimic lactose synthesis and secretion, which hinders progress in the field. This issue of optimized models for milk synthesis in vitro becomes an important area for reconciliation that would have a significant translational impact across a range of applications.

Abbreviations LALBA: $\alpha$-Lactalbumin; B4GALT1: $\beta-1,4-$ Galactosyltransferase-1 gene; CSN2: $\beta$-Casein; D: Day; EGF: Epidermal growth factor; E: Estrogen; GC: Glucocorticoid; GR: Glucocorticoid receptor; GLUT1: Glucose transporter 1; h: Hour; INS: Insulin; LII: Lactogenesis II; LS: Lactose synthase; MEC: Mammary epithelial cell; min: Minute; PRL: Prolactin; PRLR: PRL receptor; P: Progesterone; PG: Prostaglandin; STAT5: Signal tranducer and activator of transcription 5; SNP: Single nucleotide polymorphism; TRH: Thyroid hormone releasing hormone; T4: Thyroxine; T3: Trioiodothyronine; TSS: Transcription start site; UTR: Untranslated region

Supplementary Information The online version contains supplementary material available at https://doi.org/10.1007/s10911-021-09491-6.

Authors' Contributions Anna Sadovnikova-conception, review of the literature, draft preparation, editing. Sergio Garcia - conception, editing. Russell Hovey - conception, editing.

Funding This work was funded in part by a UCDavis-University of Sydney Priority Partnerships Collaboration Award to RCH and SCG. 
AS was supported by the National Institutes of Health (F30 HD101295, UL1 TR001860, and linked award TL1 TR001861), a UCDavis Henry A. Jastro Graduate Research Award, and the Daniel T. O'Connor, M.D. Memorial Research Grant. The content is solely the responsibility of the authors and does not necessarily represent the official views of the National Institutes of Health.

Data Availability Data will be made available by the corresponding author upon request.

\section{Declarations}

Consent for Publication The authors give their consent for publication.

Conflicts of Interest Russell Hovey - No conflicts, Sergio Garcia - No conflicts, Anna Sadovnikova is the Chief Executive Officer, President, and shareholder of LiquidGoldConcept, Inc.

Open Access This article is licensed under a Creative Commons Attribution 4.0 International License, which permits use, sharing, adaptation, distribution and reproduction in any medium or format, as long as you give appropriate credit to the original author(s) and the source, provide a link to the Creative Commons licence, and indicate if changes were made. The images or other third party material in this article are included in the article's Creative Commons licence, unless indicated otherwise in a credit line to the material. If material is not included in the article's Creative Commons licence and your intended use is not permitted by statutory regulation or exceeds the permitted use, you will need to obtain permission directly from the copyright holder. To view a copy of this licence, visit http://creativecommons.org/licenses/by/4.0/.

\section{References}

1. Sadovnikova, A, Garcia, SC, Hovey, RC. A comparative review of the cell biology, biochemistry, and genetics of lactose synthesis n.d.

2. Hurtaud C, Lemosquet S, Rulquin H. Effect of Graded Duodenal Infusions of Glucose on Yield and Composition of Milk from Dairy Cows. 2. Diets Based on Grass Silage. J Dairy Sci 2000;83:2952-62. https://doi.org/10.3168/jds.S0022-0302(00) 75195-2.

3. Hurtaud C, Rulquin H, Verite R. Effects of graded duodenal infusions of glucose on yield and composition of milk from dairy cows. 1. Diets based on corn silage. J Dairy Sci 1998;81:323947. https://doi.org/10.3168/jds.S0022-0302(98)75888-6.

4. Huhtanen P, Vanhatalo A, Varvikko T. Effects of abomasal infusions of histidine, glucose, and leucine on milk production and plasma metabolites of dairy cows fed grass silage diets. $\mathbf{J}$ Dairy Sci. 2002;85:204-16. https://doi.org/10.3168/jds.S00220302(02)74069-1.

5. Rigout S, Lemosquet S, van Eys JE, Blum JW, Rulquin H. Duodenal glucose increases glucose fluxes and lactose synthesis in grass silage-fed dairy cows. J Dairy Sci. 2002;85:595-606. https://doi.org/10.3168/jds.S0022-0302(02)74113-1.

6. Cai J, Zhao F-Q, Liu J-X, Wang D-M. Local Mammary Glucose Supply Regulates Availability and Intracellular Metabolic Pathways of Glucose in the Mammary Gland of Lactating Dairy Goats Under Malnutrition of Energy. Front Physiol. 2018;9:1467. https://doi.org/10.3389/fphys.2018.01467.

7. Annison EF, Linzell JL, West CE. Mammary and whole animal metabolism of glucose and fatty acids in fasting lactating goats. J Physiol. 1968;197:445-59.
8. Chaiyabutr N, Faulkner A, Peaker M. The utilization of glucose for the synthesis of milk components in the fed and starved lactating goat in vivo. Biochem J. 1980;186:301-8.

9. Linzell JL. The effect of infusions of glucose, acetate and amino acids on hourly milk yield in fed, fasted and insulin-treated goats. J Physiol. 1967;190:347-57.

10. Reid IM, Stark AJ, Isenor RN. Fasting and refeeding in the lactating dairy cow. 1 . The recovery of milk yield and blood chemistry following a six-day fast. J Comp Pathol 1977;87:241-51.

11. Mercer SW, Williamson DH. The regulation of lipogenesis in vivo in the lactating mammary gland of the rat during the starved-refed transition. Studies wtih acarbose, a glucosidase inhibitor. Biochem J 1987;242:235-43. https://doi.org/10. 1042/bj2420235.

12. Page T, Kuhn NJ. Arteriovenous glucose differences across the mammary gland of the fed, starved, and re-fed lactating rat. Biochem J. 1986;239:269-74.

13. Burnol AF, Ebner S, Ferré P, Girard J. Regulation by insulin of glucose metabolism in mammary gland of anaesthetized lactating rats. Stimulation of phosphofructokinase-1 by fructose 2,6-bisphosphate and activation of acetyl-CoA carboxylase. Biochem J 1988;254:11-4. https://doi.org/10.1042/bj2540011.

14. Prentice AM, Lamb WH, Prentice A, Coward WA. The effect of water abstention on milk synthesis in lactating women. Clin Sci Lond Engl. 1979;1984(66):291-8.

15. Zimmerman DR, Goldstein L, Lahat E, Braunstein R, Stahi D, Bar-Haim A, et al. Effect of a 24+ hour fast on breast milk composition. J Hum Lact. 2009;25:194-8. https://doi.org/10. 1177/0890334409331505.

16. Mohammad MA, Sunehag AL, Chacko SK, Pontius AS, Maningat PD, Haymond MW. Mechanisms to conserve glucose in lactating women during a 42-h fast. Am J Physiol - Endocrinol Metab. 2009;297:E879-88. https://doi.org/10. 1152/ajpendo.00364.2009.

17. Neville MC, Sawicki VS, Hay WW. Effects of fasting, elevated plasma glucose and plasma insulin concentrations on milk secretion in women. J Endocrinol. 1993;139:165-73.

18. Zucchi I, Bini L, Albani D, Valaperta R, Liberatori S, Raggiaschi $\mathrm{R}$, et al. Dome formation in cell cultures as expression of an early stage of lactogenic differentiation of the mammary gland. Proc Natl Acad Sci U S A. 2002;99:8660-5. https://doi.org/10.1073/ pnas. 132259399.

19. Anderson SM, Rudolph MC, McManaman JL, Neville MC. Key stages in mammary gland development. Secretory activation in the mammary gland: it's not just about milk protein synthesis! Breast Cancer Res BCR 2007;9:204. https://doi.org/ 10.1186/bcr1653.

20. Traurig HH. A radioautographic study of cell proliferation in the mammary gland of the pregnant mouse. Anat Rec. 1967;159:239-47. https://doi.org/10.1002/ar.1091590213.

21. Russell TD, Palmer CA, Orlicky DJ, Fischer A, Rudolph MC, Neville MC, et al. Cytoplasmic lipid droplet accumulation in developing mammary epithelial cells: roles of adipophilin and lipid metabolism. J Lipid Res. 2007;48:1463-75. https://doi. org/10.1194/jlr.M600474-JLR200.

22. Ray DB, Horst IA, Jansen RW, Mills NC, Kowal J. Normal mammary cells in long term culture. II. prolactin, corticosterone, insulin, and triiodothyronine effects on alpha-lactalbumin production. Endocrinology 1981;108:584-90. https://doi.org/ 10.1210/endo-108-2-584.

23. Burwen SJ, Pitelka DR. Secretory function of lactating mouse mammary epithelial cells cultured on collagen gels. Exp Cell Res. 1980;126:249-62. https://doi.org/10.1016/0014-4827(80) 90263-3. 
24. Cline PR. Culture of mammary epithelial cells from lactating mice: morphology and lactose synthesis. Pullman, Wash.: Washington State University; 1981.

25. Borellini F, Oka T. Growth control and differentiation in mammary epithelial cells. Environ Health Perspect. 1989;80:85-99.

26. Ling MHT. Understanding the hormonal regulation of mouse lactogenesis by transcriptomics and literature analysis 2009 .

27. Loizzi RF, de Pont JJ, Bonting SL. Inhibition by cyclic AMP of lactose production in lactating guinea pig mammary gland slices. Biochim Biophys Acta. 1975;392:20-5.

28. Perry JW, Oka T. The study of differentiative potential of the lactating mouse mammary gland in organ culture. Vitro. 1984;20:59-65.

29. Wilson GD, Woods KL, Walker RA, Howell A. Effect of prolactin on lactalbumin production by normal and malignant human breast tissue in organ culture. Cancer Res. 1980;40:486-9.

30. Quirk SJ, Gannell JE, Funder JW. Alpha-lactalbumin production by rat mammary gland: prepartum emergence of resistance to glucocorticoids and progestins. Mol Cell Endocrinol. 1988;58:183-9.

31. Wilson E, Perrin MT, Fogleman A, Chetwynd E. The intricacies of induced lactation for same-sex mothers of an adopted child. $\mathrm{J}$ Hum Lact Off J Int Lact Consult Assoc. 2015;31:64-7. https:// doi.org/10.1177/0890334414553934.

32. Wahlert L, Fiester A. Induced Lactation for the Nongestating Mother in a Lesbian Couple. AMA J Ethics. 2013;15:733-56. https://doi.org/10.1001/virtualmentor.2013.15.9.ecas2-1309.

33. Smith SD, Amos JD, Beck KN, Colvin LM, Franke KS, Liebl $\mathrm{BE}$, et al. Refinement of a Protocol for the Induction of Lactation in Nonpregnant Nonhuman Primates by Using Exogenous Hormone Treatment. J Am Assoc Lab Anim Sci JAALAS. 2014;53:700-7.

34. Stark A, Wellnitz O, Dechow C, Bruckmaier R, Baumrucker C. Colostrogenesis during an induced lactation in dairy cattle. $\mathrm{J}$ Anim Physiol Anim Nutr. 2015;99:356-66. https://doi.org/10. 1111/jpn.12205.

35. Macrina AL, Kauf ACW, Pape-Zambito DA, Kensinger RS. Induced lactation in heifers: Effects of dexamethasone and age at induction on milk yield and composition. J Dairy Sci. 2014;97:1446-53. https://doi.org/10.3168/jds.2013-7241.

36. Salama A a. K, Caja G, Albanell E, Carné S, Casals R, Such X. Mammogenesis and induced lactation with or without reserpine in nulliparous dairy goats. J Dairy Sci 2007;90:3751-7. https:// doi.org/10.3168/jds.2007-0039.

37. Cammuso C, Porter C, Nims S, Gaucher D, Melican D, Bombard S, et al. Hormonal induced lactation in transgenic goats. Anim Biotechnol. 2000;11:1-17. https://doi.org/10.1080/10495390009525943.

38. Vanklompenberg MK, Manjarin R, Trott JF, McMicking HF, Hovey RC. Late gestational hyperprolactinemia accelerates mammary epithelial cell differentiation that leads to increased milk yield. J Anim Sci. 2013;91:1102-11. https://doi.org/10. 2527/jas.2012-5903.

39. Tong JJ, Thompson IM, Zhao X, Lacasse P. Effect of the concentration of circulating prolactin on dairy cows' responsiveness to domperidone injection. J Dairy Sci. 2018;101:2579-87. https:// doi.org/10.3168/jds.2017-13828.

40. Lacasse P, Ollier S, Lollivier V, Boutinaud M. New insights into the importance of prolactin in dairy ruminants. J Dairy Sci. 2016;99:864-74. https://doi.org/10.3168/jds.2015-10035.

41. Keller SR, Abonyi-Tóth Z, Sprenger N, Austin SC, Wichert BAC, Liesegang A, et al. Effect of metoclopramide treatment of bitches during the first week of lactation on serum prolactin concentration, milk composition, and milk yield and on weight gain of their puppies. Am J Vet Res. 2018;79:233-41. https://doi.org/ 10.2460/ajvr.79.2.233.
42. Foong SC, Tan ML, Foong WC, Marasco LA, Ho JJ, Ong JH. Oral galactagogues (natural therapies or drugs) for increasing breast milk production in mothers of non-hospitalised term infants. Cochrane Database Syst Rev. 2020. https://doi.org/10. 1002/14651858.CD011505.pub2.

43. Powe CE, Puopolo KM, Newburg DS, Lönnerdal B, Chen C, Allen M, et al. Effects of Recombinant Human Prolactin on Breast Milk Composition. Pediatrics. 2011;127:e359-66. https:// doi.org/10.1542/peds.2010-1627.

44. Stuebe AM, Meltzer-Brody S, Pearson B, Pedersen C, Grewen K. Maternal Neuroendocrine Serum Levels in Exclusively Breastfeeding Mothers. Breastfeed Med. 2015;10:197-202. https://doi. org/10.1089/bfm.2014.0164.

45. Maningat PD, Sen P, Sunehag AL, Hadsell DL, Haymond MW. Regulation of gene expression in human mammary epithelium: effect of breast pumping. J Endocrinol. 2007;195:503-11. https://doi.org/10.1677/JOE-07-0394.

46. Groner B, Gouilleux F. Prolactin-mediated gene activation in mammary epithelial cells. Curr Opin Genet Dev. 1995;5:587-94.

47. Stoecklin E, Wissler M, Schaetzle D, Pfitzner E, Groner B. Interactions in the transcriptional regulation exerted by Stat 5 and by members of the steroid hormone receptor family. J Steroid Biochem Mol Biol. 1999;69:195-204.

48. Shin HY, Hennighausen L, Yoo KH. STAT5-Driven Enhancers Tightly Control Temporal Expression of Mammary-Specific Genes. J Mammary Gland Biol Neoplasia. 2019;24:61-71. https://doi.org/10.1007/s10911-018-9418-y.

49. Reichenstein M, Rauner G, Barash I. Conditional repression of STAT5 expression during lactation reveals its exclusive roles in mammary gland morphology, milk-protein gene expression, and neonate growth. Mol Reprod Dev. 2011;78:585-96. https://doi. org/10.1002/mrd.21345.

50. Warner B, Janssens P, Nicholas K. Prolactin-independent induction of alpha-lactalbumin gene expression in mammary gland explants from pregnant Balb/c mice. Biochem Biophys Res Commun. 1993;194:987-91. https://doi.org/10.1006/bbrc.1993.1918.

51. Sankaran L, Topper YJ. Selective enhancement of the induction of alpha-lactalbumin activity in rat mammary explants by epidermal growth factor. Biochem Biophys Res Commun. 1983;117:524-9. https://doi.org/10.1016/0006-291x(83)91231-7.

52. Nicholas KR, Sankaran L, Topper YJ. The induction of alphalactalbumin in rat mammary explants in the absence of exogenous prolactin: effects of progesterone and estrogen. Endocrinology. 1981;109:978-80. https://doi.org/10.1210/endo-109-3-978.

53. Dodd SC, Forsyth IA, Buttle HL, Gurr MI, Dils RR. Milk whey proteins in plasma of sows variation with physiological state. J Dairy Res. 1994;61:21-34. https://doi.org/10.1017/S0022029900028028.

54. Nicholas KR, Topper YJ. Enhancement of alpha-lactabuminlike activity in mammary explants from pregnant rats in the absence of exogenous prolactin. Biochem Biophys Res Commun. 1980;94:1424-31.

55. Sankaran L, Topper YJ. Prolactin-induced alpha-lactalbumin activity in mammary explants from pregnant rabbits. A role for epidermal growth factor and glucocorticoids. Biochem J 1984;217:833-7.

56. Bolander FF. Persistent alterations in hormonal sensitivities of mammary glands from parous mice. Endocrinology. 1983;112:1796-800. https://doi.org/10.1210/endo-112-5-1796.

57. Oppat CA, Rillema JA. Characteristics of the early effect of prolactin on lactose biosynthesis in mouse mammary gland explants. Proc Soc Exp Biol Med Soc Exp Biol Med N Y N. 1988; $188: 342-5$.

58. Jagoda CA, Rillema JA. Temporal effect of prolactin on the activities of lactose synthetase, alpha-lactalbumin, and galactosyl transferase in mouse mammary gland explants. Proc Soc Exp Biol Med Soc Exp Biol Med N Y N. 1991;197:431-4. 
59. Bolander FF, Topper YJ. Stimulation of lactose synthetase activity and casein synthesis in mouse mammary explants by estradiol. Endocrinology. 1980;106:490-5. https://doi.org/10.1210/ endo-106-2-490.

60. Turkington RW, Brew K, Vanaman TC, Hill RL. The hormonal control of lactose synthetase in the developing mouse mammary gland. J Biol Chem. 1968;243:3382-7.

61. Bowers CY, Friesen HG, Folkers K. Further evidence that TRH is also a physiological regulator of PRL secretion in man. Biochem Biophys Res Commun. 1973;51:512-21. https://doi.org/10.1016/ 0006-291X(73)91344-2.

62. Peters F, Schulze-Tollert J, Schuth W. Thyrotrophin-releasing hormone-a lactation-promoting agent? Br J Obstet Gynaecol. 1991;98:880-5. https://doi.org/10.1111/j.1471-0528.1991. tb13509.x.

63. Zarate A, Villalobos H, Canales ES, Soria J, Arcovedo F, MacGregor C. The effect of oral administration of thyrotropin-releasing hormone on lactation. J Clin Endocrinol Metab. 1976;43:301-5. https:// doi.org/10.1210/jcem-43-2-301.

64. Tyson JE, Perez A, Zanartu J. Human lactational response to oral thyrotropin releasing hormone. J Clin Endocrinol Metab. 1976;43:760-8. https://doi.org/10.1210/jcem-43-4-760.

65. Joshi JV, Bhandarkar SD, Chadha M, Balaiah D, Shah R. Menstrual irregularities and lactation failure may precede thyroid dysfunction or goitre. J Postgrad Med. 1993;39:137.

66. Davis SR, Collier RJ, McNamara JP, Head HH, Croom WJ, Wilcox CJ. Effects of thyroxine and growth hormone treatment of dairy cows on mammary uptake of glucose, oxygen and other milk fat precursors. J Anim Sci. 1988;66:80-9.

67. Davis SR, Gluckman PD, Hart IC, Henderson HV. Effects of injecting growth hormone or thyroxine on milk production and blood plasma concentrations of insulin-like growth factors I and II in dairy cows. J Endocrinol. 1987;114:17-24.

68. Capuco AV, Kahl S, Jack LJ, Bishop JO, Wallace H. Prolactin and growth hormone stimulation of lactation in mice requires thyroid hormones. Proc Soc Exp Biol Med Soc Exp Biol Med N Y N. 1999;221:345-51. https://doi.org/10.1046/j.1525-1373. 1999.d01-91.x.

69. Varas SM, Muñoz EM, Hapon MB, Aguilera Merlo CI, Giménez MS, Jahn GA. Hyperthyroidism and production of precocious involution in the mammary glands of lactating rats. Reprod Camb Engl. 2002;124:691-702.

70. Hapon MB, Simoncini M, Via G, Jahn GA. Effect of hypothyroidism on hormone profiles in virgin, pregnant and lactating rats, and on lactation. Reprod Camb Engl. 2003;126:371-82.

71. Hapon MB, Varas SM, Giménez MS, Jahn GA. Reduction of mammary and liver lipogenesis and alteration of milk composition during lactation in rats by hypothyroidism. Thyroid Off J Am Thyroid Assoc. 2007;17:11-8. https://doi.org/10.1089/ thy.2005.0267.

72. Vonderhaar BK. A role of thyroid hormones in differentiation of mouse mammary gland in vitro. Biochem Biophys Res Commun. 1975;67:1219-25.

73. Bhattacharjee M, Vonderhaar BK. Thyroid hormones enhance the synthesis and secretion of alpha-lactalbumin by mouse mammary tissue in vitro. Endocrinology. 1984;115:1070-7. https://doi.org/10.1210/endo-115-3-1070.

74. Terada N, Oka T. Selective stimulation of alpha-lactalbumin synthesis and its mRNA accumulation by thyroid hormone in the differentiation of the mouse mammary gland in vitro. FEBS Lett. 1982;149:101-4.

75. Neifert MR, McDonough SL, Neville MC. Failure of lactogenesis associated with placental retention. Am J Obstet Gynecol. 1981;140:477-8.
76. Anderson AM. Disruption of lactogenesis by retained placental fragments. J Hum Lact Off J Int Lact Consult Assoc. 2001;17:142-4. https://doi.org/10.1177/089033440101700210.

77. Deis RP, Delouis C. Lactogenesis induced by ovariectomy in pregnant rats and its regulation by oestrogen and progesterone. J Steroid Biochem. 1983;18:687-90.

78. Shinde Y, Ota K, Yokoyama A. Lactose content of mammary glands of pregnant rats near term: effect of removal of ovary, placenta and foetus. J Endocrinol. 1965;31:105-14. https://doi. org/10.1677/joe.0.0310105.

79. Shamay A, Zeelon E, Ghez Z, Cohen N, Mackinlay AG, Gertler A. Inhibition of casein and fat synthesis and alpha-lactalbumin secretion by progesterone in explants from bovine lactating mammary glands. J Endocrinol. 1987;113:81-8.

80. Lönnerdal B, Forsum E, Hambraeus L. Effect of oral contraceptives on composition and volume of breast milk. Am J Clin Nutr. 1980;33:816-24. https://doi.org/10.1093/ajcn/33.4.816.

81. Johnson HM, Eglash A, Mitchell KB, Leeper K, Smillie CM, Moore-Ostby L, et al. ABM Clinical Protocol \#32: Management of Hyperlactation. Breastfeed Med. 2020. https://doi.org/10. 1089/bfm.2019.29141.hmj.

82. Gulay MS, Hayen MJ, Head HH, Bachman KC. Short communication: Effect of estrogen supplemented at dry-off on temporal changes in concentrations of lactose in blood plasma of Holstein cows. J Dairy Sci. 2009;92:3815-8. https://doi.org/10.3168/jds. 2009-2032.

83. Athie F, Bachman KC, Head HH, Hayen MJ, Wilcox CJ. Estrogen administered at final milk removal accelerates involution of bovine mammary gland. J Dairy Sci. 1996;79:220-6. https://doi. org/10.3168/jds.S0022-0302(96)76354-3.

84. Peaker M, Linzell JL. The effects of oestrus and exogenous oestrogens on milk secretion in the goat. J Endocrinol. 1974;61:23140. https://doi.org/10.1677/joe.0.0610231.

85. Fulkerson WJ, McDowell GH. Effect of oestrogen administered in early or late lactation on the yield and composition of milk in sheep. J Endocrinol. 1974;63:175-80. https://doi.org/10.1677/ joe. 0.0630175 .

86. Bussmann LE, Koninckx A, Deis RP. Effect of estrogen and placental lactogen on lactogenesis in pregnant rats. Biol Reprod. 1983;29:535-41.

87. Casey TM, Plaut K. The Role of Glucocorticoids in Secretory Activation and Milk Secretion, a Historical Perspective. J Mammary Gland Biol Neoplasia. 2007;12:293-304. https://doi.org/10.1007/ s10911-007-9055-3.

88. Rivera EM. Interchangeability of adrenocortical hormones in initiating mammary secretion in vitro. Proc Soc Exp Biol Med Soc Exp Biol Med N Y N. 1964;116:568-72.

89. Tucker HA. Induction of lactation in pregnant heifers with 9-fluoroprednisolone acetate. J Dairy Sci. 1965;48:403-5. https://doi.org/10.3168/jds.s0022-0302(65)88238-8.

90. Henderson JJ, Hartmann PE, Moss TJM, Doherty DA, Newnham JP. Disrupted secretory activation of the mammary gland after antenatal glucocorticoid treatment in sheep. Reprod Camb Engl. 2008;136:649-55. https://doi.org/10.1530/REP-08-0134.

91. Henderson JJ, Hartmann PE, Newnham JP, Simmer K. Effect of preterm birth and antenatal corticosteroid treatment on lactogenesis II in women. Pediatrics. 2008;121:e92-100. https://doi.org/ 10.1542/peds.2007-1107.

92. Henderson JJ, Newnham JP, Simmer K, Hartmann PE. Effects of antenatal corticosteroids on urinary markers of the initiation of lactation in pregnant women. Breastfeed Med Off $\mathrm{J}$ Acad Breastfeed Med. 2009;4:201-6. https://doi.org/10.1089/bfm.2008.0136.

93. Stewart HJ, Walker FM. ACTH initiation of mammary secretion in pregnant goats is influenced by the stage of gestation and pre partum milking. J Dairy Res. 1987;54:179-91. 
94. Wiener Y, Tomashev R, Berlin M, Melcer Y, Maymon R. Breast Engorgement Induced by Antenatal Betamethasone Therapy in a Woman After Mammoplasty. Breastfeed Med Off J Acad Breastfeed Med. 2017;12:659-60. https://doi.org/10.1089/bfm.2017. 0076.

95. Tallo-Parra O, Carbajal A, Monclús L, Manteca X, Lopez-Bejar M. Hair cortisol and progesterone detection in dairy cattle: interrelation with physiological status and milk production. Domest Anim Endocrinol. 2018;64:1-8. https://doi.org/10.1016/j.domaniend.2018.02. 001.

96. Caroprese M, Albenzio M, Marzano A, Schena L, Annicchiarico G, Sevi A. Relationship between cortisol response to stress and behavior, immune profile, and production performance of dairy ewes. J Dairy Sci. 2010;93:2395-403. https://doi.org/10.3168/ jds.2009-2604.

97. Stuebe AM, Grewen K, Pedersen CA, Propper C, Meltzer-Brody S. Failed Lactation and Perinatal Depression: Common Problems with Shared Neuroendocrine Mechanisms? J Womens Health. 2012;21:264-72. https://doi.org/10.1089/jwh.2011.3083.

98. McGuire E. Sudden loss of milk supply following highdosetriamcinolone (Kenacort) injection. Breastfeed Rev. 2012;20:32.

99. Babwah TJ, Nunes P, Maharaj RG. An unexpected temporary suppression of lactation after a local corticosteroid injection for tenosynovitis. Eur J Gen Pract. 2013;19:248-50. https://doi.org/ 10.3109/13814788.2013.805198.

100. Ponchon B, Zhao X, Ollier S, Lacasse P. Relationship between glucocorticoids and prolactin during mammary gland stimulation in dairy cows. J Dairy Sci. 2017;100:1521-34. https://doi.org/10. 3168/jds.2016-11490.

101. Glaubach S. Effect of excessive doses of cortisone, ACTH and prolactin in pregnant and nursing mice. J Mt Sinai Hosp N Y. 1952;19:84-90.

102. Mercier-Parot L. Post-natal growth disorders in rats after administration of cortisone to the mother in pregnancy or lactation. Comptes Rendus Hebd Seances Acad Sci. 1955;240:2259-61.

103. Llopis J, Lampreabe A, López Frías M, Perán F, Blanco Martínez $\mathrm{N}$, Urbano $\mathrm{G}$, et al. Influence of hydrocortisone acetate administered to the lactating rat on protein and lactose content in milk and serum protein, glucose and insulin levels in dams and pups. Horm Metab Res Horm Stoffwechselforschung Horm Metab. 1990;22:71-4. https://doi.org/10.1055/s-2007-1004854.

104. Lee DY, Kim E, Choi MH. Technical and clinical aspects of cortisol as a biochemical marker of chronic stress. BMB Rep. 2015;48:209-16. https://doi.org/10.5483/BMBRep.2015.48.4. 275.

105. Varner MA, Johnson BH. Influence of Adrenocorticotropin upon Milk Production, Milk Constituents, and Endocrine Measures of Dairy Cows1. J Dairy Sci. 1983;66:458-65.

106. Hong H, Lee E, Lee IH, Lee S-R. Effects of transport stress on physiological responses and milk production in lactating dairy cows. Asian-Australas J Anim Sci. 2019;32:442-51. https://doi. org/10.5713/ajas.18.0108.

107. Shamay A, Mabjeesh SJ, Shapiro F, Silanikove N. Adrenocorticotrophic hormone and dexamethasone failed to affect milk yield in dairy goats: comparative aspects. Small Rumin Res. 2000;38:255-9.

108. Romero G, Restrepo I, Muelas R, Bueso-Ródenas J, Roca A, Díaz JR. Within-day variation and effect of acute stress on plasma and milk cortisol in lactating goats. J Dairy Sci. 2015;98:832-9. https://doi.org/10.3168/jds.2014-8052.

109. Bomfim GF, Merighe GKF, de Oliveira SA, Negrao JA. Effect of acute stressors, adrenocorticotropic hormone administration, and cortisol release on milk yield, the expression of key genes, proliferation, and apoptosis in goat mammary epithelial cells. J Dairy Sci. 2018;101:6486-96. https://doi.org/10.3168/jds.2017-14123.
110. Ono M, Perry JW, Oka T. Concentration-dependent differential effects of cortisol on synthesis of alpha-lactalbumin and of casein in cultured mouse mammary gland explants: importance of prolactin concentration. Vitro. 1981;17:121-8.

111. Quirk SJ, Gannell JE, Fullerton MJ, Funder JW. Progestins specifically suppress alpha-lactalbumin synthesis and secretion. J Steroid Biochem. 1985;23:901-5.

112. Nagamatsu Y, Oka T. The differential actions of cortisol on the synthesis and turnover of alpha-lactalbumin and casein and on accumulation of their mRNA in mouse mammary gland in organ culture. Biochem J. 1983;212:507-15.

113. Bolander FF, Topper YJ. The asynchronous hormonal induction of lactose synthetase components, alpha-lactalbumin and galactosyltransferase, in relation to lactose secretion by mouse mammary explants. Endocrinology. 1981;108:1594-6. https:// doi.org/10.1210/endo-108-4-1594.

114. Cline PR, Zamora PO, Hosick HL. Morphology and lactose synthesis in tissue culture of mammary alveoli isolated from lactating mice. Vitro. 1982;18:694-702.

115. Taketani Y, Oka T. Hormonal regulation of the synthesis of casein and alpha-lactalbumin in a primary mammary cell culture system. Horm Metab Res Horm Stoffwechselforschung Horm Metab. 1986;18:119-25. https://doi.org/10.1055/s-20071012246.

116. Taketani Y, Oka T. Epidermal growth factor stimulates cell proliferation and inhibits functional differentiation of mouse mammary epithelial cells in culture. Endocrinology. 1983;113:871-7. https://doi.org/10.1210/endo-113-3-871.

117. Williamson DH, Stewart HJ, Robinson AM. Effects of progesterone on glucose metabolism in isolated acini from mammary glands of lactating rats. Arch Biochem Biophys. 1979;198:462-9.

118. Collier RJ, Tucker HA. Regulation of cortisol uptake in mammary tissue of cows. J Dairy Sci. 1978;61:1709-14.

119. Capuco AV, Feldhoff PA, Akers RM, Wittliff JL, Tucker HA. Progestin binding in mammary tissue of prepartum, nonlactating and postpartum, lactating cows. Steroids. 1982;40:503-17. https://doi.org/10.1016/0039-128X(82)90072-1.

120. Ray DB, Horst IA, Jansen RW, Littlejohn RA, Kowal J. Glucocorticoid regulation of alpha-lactalbumin production in longterm cultures of normal rat mammary cells. Endocr Res Commun. 1981;8:165-78.

121. Terada N, Leiderman LJ, Oka T. The interaction of cortisol and prostaglandins on the phenotypic expression of the alpha-lactalbumin gene in the mouse mammary gland in culture. Biochem Biophys Res Commun. 1983;111:1059-65.

122. Terada N, Ono M, Nagamatsu Y, Oka T. The reversal of cortisolinduced inhibition of alpha-lactalbumin production by prostaglandins in the mouse mammary gland in culture. J Biol Chem. 1982;257:11199-202.

123. Oka T, Perry JW. Spermidine as a possible mediator of glucocorticoid effect on milk protein synthesis in mouse mammary epithelium in vitro. J Biol Chem. 1974;249:7647-52.

124. Bolander FF, Topper YJ. Relationships between spermidine, glucocorticoid and milk proteins in different mammalian species. Biochem Biophys Res Commun. 1979;90:1131-5. https://doi. org/10.1016/0006-291X(79)91153-7.

125. Menzies KK, Lee HJ, Lefèvre C, Ormandy CJ, Macmillan KL, Nicholas KR. Insulin, a key regulator of hormone responsive milk protein synthesis during lactogenesis in murine mammary explants. Funct Integr Genomics. 2010;10:87-95. https://doi.org/ 10.1007/s10142-009-0140-0.

126. Menzies KK, Lefèvre C, Macmillan KL, Nicholas KR. Insulin regulates milk protein synthesis at multiple levels in the bovine mammary gland. Funct Integr Genomics. 2009;9:197-217. https://doi.org/10.1007/s10142-008-0103-x. 
127. Cohick WS. PHYSIOLOGY AND ENDOCRINOLOGY SYMPOSIUM: Effects of insulin on mammary gland differentiation during pregnancy and lactation. J Anim Sci. 2016;94:1812-20. https://doi.org/10.2527/jas.2015-0085.

128. Nommsen-Rivers LA. Does Insulin Explain the Relation between Maternal Obesity and Poor Lactation Outcomes? An Overview of the Literature. Adv Nutr. 2016;7:407-14. https://doi.org/10. 3945/an.115.011007.

129. Vernon RG, Faulkner A, Hay WW, Calvert DT, Flint DJ. Insulin resistance of hind-limb tissues in vivo in lactating sheep. Biochem J. 1990;270:783-6. https://doi.org/10.1042/bj2700783.

130. McGuire MA, Griinari JM, Dwyer DA, Bauman DE. Role of Insulin in the Regulation of Mammary Synthesis of Fat and Protein. J Dairy Sci. 1995;78:816-24. https://doi.org/10.3168/jds. S0022-0302(95)76693-0.

131. Hayirli A, Bertics SJ, Grummer RR. Effects of Slow-release Insulin on Production, Liver Triglyceride, and Metabolic Profiles of Holsteins in Early Lactation. J Dairy Sci. 2002;85:2180-91. https://doi.org/10.3168/jds.S0022-0302(02)74297-5.

132. Jahn GA, Deis RP. Involvement of the adrenergic system on the release of prolactin and lactogenesis at the end of pregnancy in the rat. J Endocrinol. 1991;129:343-50.

133. Perry JW, Oka T. Cyclic AMP as a negative regulator of hormonally induced lactogenesis in mouse mammary gland organ culture. Proc Natl Acad Sci U S A. 1980;77:2093-7.

134. Oppat CA, Rillema JA. Cyclic nucleotides and polyamines in prolactin stimulation of lactose biosynthesis. Am J Physiol. 1989;257:E318-322. https://doi.org/10.1152/ajpendo.1989.257.3. E318.

135. Komura H, Wakimoto $\mathrm{H}$, Chen $\mathrm{CF}$, Terakawa N, Aono $\mathrm{T}$, Tanizawa $\mathrm{O}$, et al. Retinoic acid enhances cell responses to epidermal growth factor in mouse mammary gland in culture. Endocrinology. 1986;118:1530-6. https://doi.org/10.1210/ endo-118-4-1530.

136. Gow CB, Moore GP. Epidermal growth factor alters milk composition and fluid balance of lactating ewes. J Endocrinol. 1992;132:377-85.

137. Sankaran L, Topper YJ. Progesterone and prolactin are both required for suppression of the induction of rat alpha-lactalbumin activity. Biochem Biophys Res Commun. 1988;155:1038-45.

138. Zhao $\mathrm{H}, \mathrm{Wu} \mathrm{X}$, Cai H, Pan $\mathrm{C}$, Lei $\mathrm{C}$, Chen $\mathrm{H}$, et al. Genetic variants and effects on milk traits of the caprine paired-like homeodomain transcription factor 2 (PITX2) gene in dairy goats. Gene. 2013;532:203-10. https://doi.org/10.1016/j.gene.2013.09.062.

139. Kusza S, Cziszter LT, Ilie DE, Sauer M, Padeanu I, Gavojdian D. Kompetitive Allele Specific PCR (KASP ${ }^{\mathrm{TM}}$ ) genotyping of 48 polymorphisms at different caprine loci in French Alpine and Saanen goat breeds and their association with milk composition. PeerJ. 2018;6:e4416. https://doi.org/10.7717/peerj.4416.

140. Ozmen O, Kul S, Unal EO. Polymorphism of sheep POU1F1 gene exon 6 and 3'UTR region and their association with milk production traits. Iran J Vet Res. 2014;15:331-5.

141. Dettori ML, Pazzola M, Paschino P, Amills M, Vacca GM. Association between the GHR, GHRHR, and IGF1 gene polymorphisms and milk yield and quality traits in Sarda sheep. J Dairy Sci. 2018;101:9978-86. https://doi.org/10.3168/jds.2018-14914.

142. Jawasreh K, Amareen AA, Aad P. Effect and Interaction of $\beta$-Lactoglobulin, Kappa Casein, and Prolactin Genes on Milk Production and Composition of Awassi Sheep. Anim Open Access J MDPI 2019;9. https://doi.org/10.3390/ani9060382.

143. Glantz M, Lindmark Månsson H, Stålhammar H, Paulsson M. Effect of polymorphisms in the leptin, leptin receptor and acylCoA:diacylglycerol acyltransferase 1 (DGAT1) genes and genetic polymorphism of milk proteins on bovine milk composition. J Dairy Res. 2012;79:110-8. https://doi.org/10.1017/S0022029911000859.
144. Littlejohn MD, Tiplady K, Lopdell T, Law TA, Scott A, Harland $\mathrm{C}$, et al. Expression variants of the lipogenic AGPAT6 gene affect diverse milk composition phenotypes in Bos taurus. PLoS ONE. 2014;9:e85757. https://doi.org/10.1371/journal.pone.0085757.

145. Rahmatalla SA, Müller U, Strucken EM, Reissmann M, Brockmann GA. The F279Y polymorphism of the GHR gene and its relation to milk production and somatic cell score in German Holstein dairy cattle. J Appl Genet. 2011;52:459-65. https://doi.org/10.1007/ s13353-011-0051-3.

146. Cecchinato A, Ribeca C, Chessa S, Cipolat-Gotet C, Maretto F, Casellas J, et al. Candidate gene association analysis for milk yield, composition, urea nitrogen and somatic cell scores in Brown Swiss cows. Anim Int J Anim Biosci. 2014;8:1062-70. https://doi.org/10.1017/S1751731114001098.

147. Houaga I, Muigai AWT, Ng'ang'a FM, Ibeagha-Awemu EM, Kyallo M, Youssao IAK, et al. Milk fatty acid variability and association with polymorphisms in SCD1 and DGAT1 genes in White Fulani and Borgou cattle breeds. Mol Biol Rep 2018;45:1849-62. https://doi.org/10.1007/s11033-018-4331-4.

148. Szyndler-Nędza M, Tyra M, Ropka-Molik K, Piórkowska K, Mucha A, Różycki M, et al. Association between LEPR and MC4R genes polymorphisms and composition of milk from sows of dam line. Mol Biol Rep. 2013;40:4339-47. https://doi.org/10. 1007/s11033-013-2524-4.

149. Charron M, Shaper JH, Shaper NL. The increased level of beta1,4-galactosyltransferase required for lactose biosynthesis is achieved in part by translational control. Proc Natl Acad Sci U S A. 1998;95:14805-10.

150. Rajput B, Shaper NL, Shaper JH. Transcriptional regulation of murine beta1,4-galactosyltransferase in somatic cells. Analysis of a gene that serves both a housekeeping and a mammary glandspecific function. J Biol Chem 1996;271:5131-42.

151. Shahbazkia HR, Aminlari M, Cravador A. Association of polymorphism of the $\beta(1,4)$-galactosyltransferase-I gene with milk production traits in Holsteins. Mol Biol Rep. 2012;39:6715-21. https://doi.org/10.1007/s11033-012-1495-1.

152. Qasba PK, Kumar S. Molecular divergence of lysozymes and alpha-lactalbumin. Crit Rev Biochem Mol Biol. 1997;32:255306. https://doi.org/10.3109/10409239709082574.

153. Hall L, Emery DC, Davies MS, Parker D, Craig RK. Organization and sequence of the human alpha-lactalbumin gene. Biochem J. 1987;242:735-42.

154. Vilotte J-L, Soulier S. Isolation and characterization of the mouse $\alpha$-lactalbumin-encoding gene: interspecies comparison, tissueand stage-specific expression. Gene. 1992;119:287-92. https:// doi.org/10.1016/0378-1119(92)90285-W.

155. Vilotte JL, Soulier S, Mercier JC, Gaye P, Hue-Delahaie D, Furet JP. Complete nucleotide sequence of bovine alpha-lactalbumin gene: comparison with its rat counterpart. Biochimie. 1987;69:609-20.

156. Vilotte JL, Soulier S, Printz C, Mercier JC. Sequence of the goat $\alpha$-lactalbumin-encoding gene: comparison with the bovine gene and evidence of related sequences in the goat genome. Gene. 1991;98:271-6. https://doi.org/10.1016/0378-1119(91)90185-E.

157. Laird JE, Jack L, Hall L, Boulton AP, Parker D, Craig RK. Structure and expression of the guinea-pig $\alpha$-lactalbumin gene. Biochem J. 1988;254:85-94. https://doi.org/10.1042/bj2540085.

158. Malewski T. Computer analysis of distribution of putative cisand trans- regulatory elements in milk protein gene promoters. Biosystems. 1998;45:29-44. https://doi.org/10.1016/S03032647(97)00059-2.

159. Lubon H, Hennighausen L. Conserved region of the rat alphalactalbumin promoter is a target site for protein binding in vitro. Biochem J. 1988;256:391-6.

160. Rijnkels M, Freeman-Zadrowski C, Hernandez J, Potluri V, Wang $\mathrm{L}, \mathrm{Li}$ W, et al. Epigenetic Modifications Unlock the Milk Protein Gene Loci during Mouse Mammary Gland Development and 
Differentiation. PLoS ONE. 2013;8:e53270. https://doi.org/10. 1371/journal.pone.0053270.

161. Lubon H, Hennighausen L. Conserved region of the rat $\alpha$-lactalbumin promoter is a target site for protein binding in vitro. Biochem J. 1988;256:391-6. https://doi.org/10.1042/bj2560391.

162. Watson CJ, Gordon KE, Robertson M, Clark AJ. Interaction of DNA-binding proteins with a milk protein gene promoter in vitro: identification of a mammary gland-specific factor. Nucleic Acids Res. 1991;19:6603-10. https://doi.org/10.1093/ nar/19.23.6603.

163. Vilotte J-L, Soulier S, Mercier J-C. Sequence of the murine $\alpha$-lactalbumin-encoding cDNA: interspecies comparison of the coding frame and deduced preprotein. Gene. 1992;112:251-5. https://doi.org/10.1016/0378-1119(92)90385-3.

164. Collet C, Joseph R, Nicholas K. Cloning, cDNA analysis and prolactin-dependent expression of a marsupial alpha-lactalbumin. Reprod Fertil Dev. 1990;2:693-701. https://doi.org/10.1071/ rd9900693.

165. Bleck GT, Bremel RD. Sequence and single-base polymorphisms of the bovine alpha-lactalbumin 5'-flanking region. Gene. 1993;126:213-8.

166. Schmidhauser C, Casperson GF, Myers CA, Sanzo KT, Bolten $\mathrm{S}$, Bissell MJ. A novel transcriptional enhancer is involved in the prolactin- and extracellular matrix-dependent regulation of beta-casein gene expression. Mol Biol Cell. 1992;3:699-709.

167. Winklehner-Jennewein P, Geymayer S, Lechner J, Welte T, Hansson L, Geley S, et al. A distal enhancer region in the human beta-casein gene mediates the response to prolactin and glucocorticoid hormones. Gene. 1998;217:127-39.

168. Bolander FF. Enhanced endocrine sensitivity in mouse mammary glands: hormonal requirements for induction and maintenance. Endocrinology. 1984;115:630-3. https://doi.org/10.1210/ endo-115-2-630.

169. Maynard F. Identification of a new molecular form of human $\alpha$-lactalbumin. J Dairy Res. 1992;59:425-9. https://doi.org/10. 1017/S0022029900030697.

170. Chowanadisai W, Kelleher SL, Nemeth JF, Yachetti S, Kuhlman $\mathrm{CF}$, Jackson JG, et al. Detection of a single nucleotide polymorphism in the human $\alpha$-lactalbumin gene: implications for human milk proteins. J Nutr Biochem. 2005;16:272-8. https://doi.org/ 10.1016/j.jnutbio.2004.12.010.

171. Bleck GT, Bremel RD. Correlation of the $\alpha$-Lactalbumin $(+15)$ Polymorphism to Milk Production and Milk Composition of Holsteins. J Dairy Sci. 1993;76:2292-8. https://doi.org/10.3168/jds. S0022-0302(93)77566-9.

172. Zidi A, Casas E, Amills M, Jordana J, Carrizosa J, Urrutia $\mathrm{B}$, et al. Genetic variation at the caprine lactalbumin, alpha (LALBA) gene and its association with milk lactose concentration. Anim Genet. 2014;45:612-3. https://doi.org/10.1111/age. 12152.

173. Soyudal B, Ardicli S, Samli H, Dincel D, Balci F. Association of polymorphisms in the CSN2, CSN3, LGB and LALBA genes with milk production traits in Holstein cows raised in Turkey. J Hell Vet Med Soc 2018;69:1271-82. https://doi.org/10.12681/ jhvms.19617.

174. Habib M, Hazari YM, Iqbal ST, Ganai TAS, Sheikh FD, Andrabi KI, et al. Novel variations in $5^{\prime}$ flanking region of the $\alpha$-Lactalbumin gene in exotic and indigenous cattle. Meta Gene. 2017;13:149-53. https://doi.org/10.1016/j.mgene.2017.06.004.

175. Zhou JP, Dong CH. Association between a polymorphism of the $\alpha$-lactalbumin gene and milk production traits in Chinese Holstein cows. Genet Mol Res GMR. 2013;12:3375-82. https:// doi.org/10.4238/2013.September.4.3.

176. Noce A, Pazzola M, Dettori ML, Amills M, Castelló A, Cecchinato $\mathrm{A}$, et al. Variations at regulatory regions of the milk protein genes are associated with milk traits and coagulation properties in the Sarda sheep. Anim Genet. 2016;47:717-26. https://doi.org/10.1111/age. 12474.

177. Wodas Ł, Maćkowski M, Borowska A, Pawlak P, Puppel K, Kuczyńska B, et al. 5 '-flanking variants of the equine $\alpha$-lactalbumin ( LALBA ) gene - relationship with gene expression and mare's milk composition. J Anim Feed Sci 2018;27:317-26. https://doi. org/10.22358/jafs/97175/2018.

178. Lundén A, Lindersson M. a-Lactalbumin polymorphism in relation to milk lactose. Proc. 6th World Congr. Genet. Appl Livest Prod. 1998.

179. McFadden TB, Akers RM, Beal WE. Influence of breed and hormones on production of milk proteins by mammary explants from prepubertal heifers. J Dairy Sci. 1989;72:1754-63. https:// doi.org/10.3168/jds.S0022-0302(89)79292-4.

180. Yang F, Zhang M, Rong Y, Liu Z, Yang S, Zhang W, et al. A Novel SNPs in Alpha-Lactalbumin Gene Effects on Lactation Traits in Chinese Holstein Dairy Cows. Anim Open Access J MDPI 2019;10. https://doi.org/10.3390/ani10010060.

181. Dettori ML, Pazzola M, Paschino P, Pira MG, Vacca GM. Variability of the caprine whey protein genes and their association with milk yield, composition and renneting properties in the Sarda breed. 1. The LALBA gene. J Dairy Res 2015;82:43441. https://doi.org/10.1017/S0022029915000461.

182. Sharp JA, Lefèvre C, Nicholas KR. Lack of functional alphalactalbumin prevents involution in Cape fur seals and identifies the protein as an apoptotic milk factor in mammary gland involution. BMC Biol. 2008;6:48. https://doi.org/10.1186/ 1741-7007-6-48.

183. Reich CM, Arnould JPY. Evolution of Pinnipedia lactation strategies: a potential role for alpha-lactalbumin? Biol Lett. 2007;3:546-9. https://doi.org/10.1098/rsbl.2007.0265.

184. Cant JP, Kim JJM, Cieslar SRL, Doelman J. Symposium review: Amino acid uptake by the mammary glands: Where does the control lie? J Dairy Sci. 2018;101:5655-66. https://doi.org/10. 3168/jds.2017-13844.

185. Prasad R, Hudson BG, Butkowski R, Hamilton JW, Ebner KE. Resolution of the charge forms and amino acid sequence and location of a tryptic glycopeptide in rat alpha-lactalbumin. J Biol Chem. 1979;254:10607-14.

186. Chianese L, Caira S, Lilla S, Pizzolongo F, Ferranti P, Pugliano $\mathrm{G}$, et al. Primary structure of water buffalo alpha-lactalbumin variants A and B. J Dairy Res. 2004;71:14-9.

187. Saito A, Usui M, Song Y, Azakami H, Kato A. Secretion of glycosylated alpha-lactalbumin in yeast Pichia pastoris. J Biochem (Tokyo). 2002;132:77-82. https://doi.org/10.1093/oxfordjournals. jbchem.a003202.

188. Shailubhai K, Saxena ES, Balapure AK, Vijay IK. Developmental regulation of glucosidase $\mathrm{I}$, an enzyme involved in the processing of asparagine-linked glycoproteins in rat mammary gland. J Biol Chem. 1990;265:9701-6.

189. Ziska SE, Bhattacharjee M, Herber RL, Qasba PK, Vonderhaar BK. Thyroid hormone regulation of alpha-lactalbumin: differential glycosylation and messenger ribonucleic acid synthesis in mouse mammary glands. Endocrinology. 1988;123:2242-8. https://doi.org/10.1210/endo-123-5-2242.

190. Persuy M-A, Legrain S, Printz C, Stinnakre M-G, Lepourry L, Brignon G, et al. High-level, stage- and mammary-tissue-specific expression of a caprine $\kappa$-casein-encoding minigene driven by a $\beta$-casein promoter in transgenic mice. Gene. 1995;165:291-6. https://doi.org/10.1016/0378-1119(95)00405-U.

191. Soulier S, Vilotte JL, Stinnakre MG, Mercier JC. Expression analysis of ruminant alpha-lactalbumin in transgenic mice: developmental regulation and general location of important cisregulatory elements. FEBS Lett. 1992;297:13-8.

192. Bleck GT, Bremel RD. Variation in expression of a bovine alphalactalbumin transgene in milk of transgenic mice. J Dairy Sci. 
1994;77:1897-904. https://doi.org/10.3168/jds.S0022-0302(94) 77132-0.

193. Stinnakre MG, Vilotte JL, Soulier S, Mercier JC. Creation and phenotypic analysis of alpha-lactalbumin-deficient mice. Proc Natl Acad Sci U S A. 1994;91:6544-8.

194. Bleck GT, Jiménez-Flores R, Bremel RD. Abnormal properties of milk from transgenic mice expressing bovine $\beta$-casein under control of the bovine $\alpha$-lactalbumin 5' flanking region. Int Dairy J. 1995;5:619-32. https://doi.org/10.1016/0958-6946(94)00025-K.

195. Stacey A, Schnieke A, Kerr M, Scott A, McKee C, Cottingham I, et al. Lactation is disrupted by alpha-lactalbumin deficiency and can be restored by human alpha-lactalbumin gene replacement in mice. Proc Natl Acad Sci U S A. 1995;92:2835-9. https://doi. org/10.1073/pnas.92.7.2835.

196. Noble MS, Walter L. Hurley. Characterization of Lactational Performance in Transgenic Swine Overexpressing Alpha-Lactalbumin. 2001.

197. Noble MS, Rodriguez-Zas S, Cook JB, Bleck GT, Hurley WL, Wheeler MB. Lactational performance of first-parity transgenic gilts expressing bovine alpha-lactalbumin in their milk. J Anim Sci. 2002;80:1090-6. https://doi.org/10.2527/2002.8041090x.
198. Wang J, Yang P, Tang B, Sun X, Zhang R, Guo C, et al. Expression and Characterization of Bioactive Recombinant Human $\alpha$-Lactalbumin in the Milk of Transgenic Cloned Cows. J Dairy Sci. 2008;91:4466-76. https://doi.org/10.3168/jds.2008-1189.

199. Jeng SY, Bleck GT, Wheeler MB, Jiménez-Flores R. Characterization and partial purification of bovine alpha-lactalbumin and beta-casein produced in milk of transgenic mice. J Dairy Sci. 1997;80:3167-75. https://doi.org/10.3168/jds.S0022-0302(97) 76288-X

200. Sui S, Zhao J, Wang J, Zhang R, Guo C, Yu T, et al. Comparative proteomics of milk fat globule membrane proteins from transgenic cloned cattle. PLoS ONE. 2014;9:e105378. https://doi.org/ 10.1371/journal.pone.0105378.

Publisher's Note Springer Nature remains neutral with regard to jurisdictional claims in published maps and institutional affiliations. 